\title{
Paraguay: Selected Issues
}

This Selected Issues paper for Paraguay was prepared by a staff team of the International Monetary Fund as background documentation for the periodic consultation with the member country. It is based on the information available at the time it was completed on April 29, 2009. The views expressed in this document are those of the staff team and do not necessarily reflect the views of the government of Paraguay or the Executive Board of the IMF.

The policy of publication of staff reports and other documents by the IMF allows for the deletion of market-sensitive information.

Copies of this report are available to the public from

International Monetary Fund $\bullet$ Publication Services

700 19th Street, N.W. • Washington, D.C. 20431

Telephone: (202) 623-7430 • Telefax: (202) 623-7201

E-mail: publications@imf.org • Internet: http://www.imf.org

\section{International Monetary Fund \\ Washington, D.C.}





\section{INTERNATIONAL MONETARY FUND}

\section{PARAGUAY}

\section{Selected Issues}

Prepared by Montfort Mlachila and Brieuc Monfort

Approved by the Western Hemisphere Department

April 29, 2009

Contents

I. Assessing the Appropriateness of Monetary and Fiscal Policies in an

Adverse External Environment ......................................................................... 3

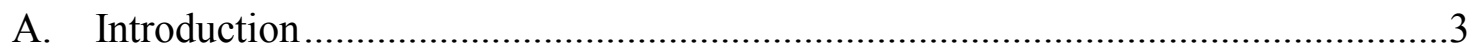

B. Where Does Paraguay Stand in Terms of Business Cycle? ...................................3

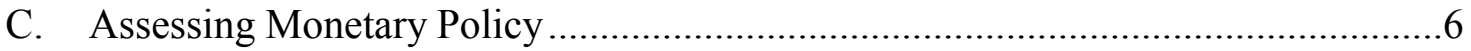

D. Assessing the Need for Fiscal Stimulues ......................................................... 12

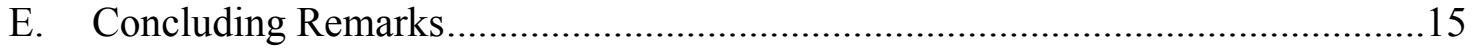

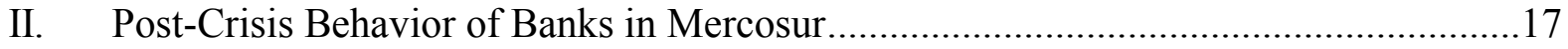

A. Introduction.......................................................................................... 17

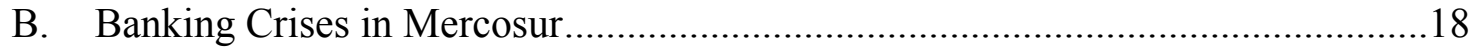

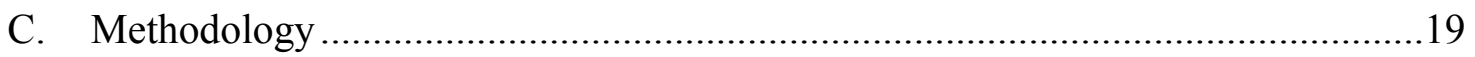

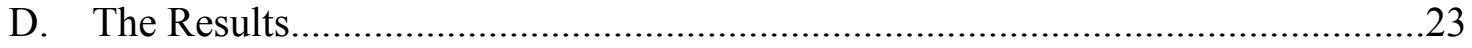

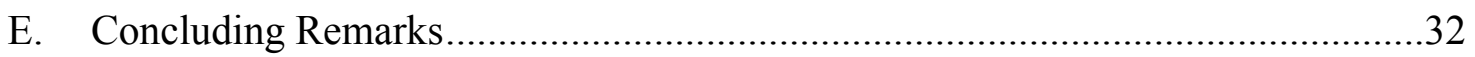

Box

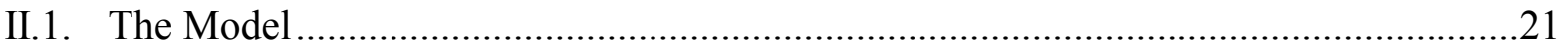

Figures

I.1. GDP Growth, Investment, and Output Gap ....................................................

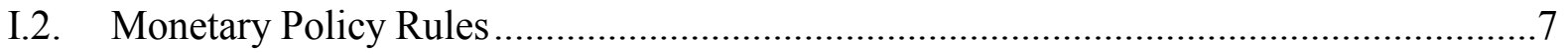

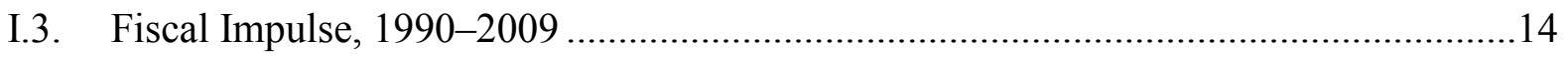

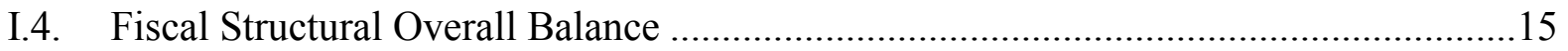


Tables

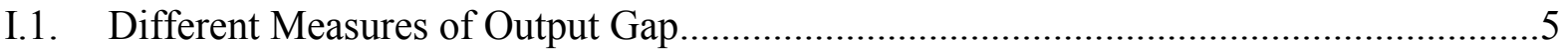

I.2. Testing Different Monetary Rules in Paraguay, 2003-08 ........................................ 10

I.3. Future Path of Interest Rates, 2008Q4-2009Q4 ......................................................12

II.1. Overview of Demand and Supply Conditions on Credit Allocation ...........................17

II.2. Overview of Financial Crises in Individual Countries...........................................20

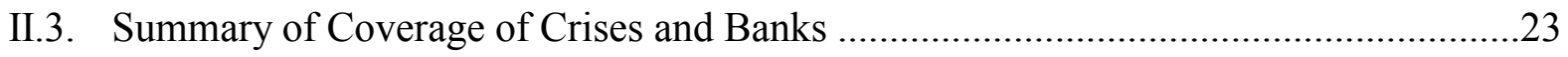

II.4. Bank Behavior Summary Statistics................................................................25

II.5. Summary Results for Absolute and Conditional Convergence..................................26

II.6. Results for Absolute and Conditional Sigma Convergence by Country .......................29

II.7. Summary Results for Sigma Convergence Using Chile and Norway as

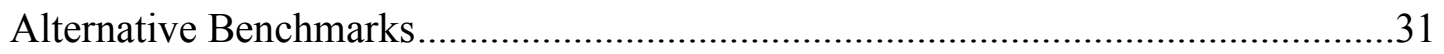

Appendix

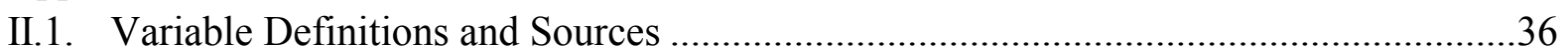




\section{Assessing the Appropriateness of Monetary ANd Fiscal Policies in AN ADVERSE EXTERNAL ENVIRONMENT ${ }^{1}$}

\section{A. Introduction}

1. This paper assesses the appropriateness of monetary and fiscal policies in the context of the current global economic crisis. After five years of high growth led in part by agro-exporting sectors, the external environment has turned less favorable, with a sharp decline of export prices and a curtailment of external credit lines. Over the same period, inflation remained above 5 percent, but hovered around 10 percent in the last two years, fed in part by supply shocks but possibly also by an overheating of the economy. The decline of global demand has contributed to a partial reversal of these supply shocks. This combined with the prospect of a weakening domestic demand, has been lowering inflationary pressures for 2009.

2. To determine how monetary and fiscal policies should react, one first needs to ascertain the cyclical position of the economy. This paper updates the assessment of macroeconomic policies done in Monfort and Santos (2007), covering the output gap, the monetary stance, and the fiscal stance. It also extends it in a number of dimensions. The assessment is forward-looking rather than backward-looking. Regarding the calculation of the output gap, given the importance of the primary sector in the recent economic performance, we distinguish between total GDP and non-primary sector GDP, using both low- and highfrequency data. Concerning the assessment and recommendation on monetary policies, the paper adopts a normative approach, looking at what the monetary authorities would have done if they had followed different variants of a Taylor rule. Finally, the last section on the fiscal stance presents a forward looking assessment of fiscal policy, ascertaining whether an additional fiscal stimulus is needed beyond the current period.

\section{B. Where Does Paraguay Stand in Terms of Business Cycle?}

3. This section uses different methodologies to assess the situation of the business cycle. We use different statistical filters (Hodrick-Prescott, Christiano Fitzgerald) as well as a production function. Given the importance of the primary sector for the most recent growth pickup, it also makes sense to distinguish between total and non-primary sector GDP. During 2003-2008, GDP growth has averaged 5.0 percent, in sharp contrast to an average 0.5 percent decline during 1998-2002 (Figure 1). The improvement in economic performance reflects better economic management, as well as the boom in primary commodities. ${ }^{2}$

\footnotetext{
${ }^{1}$ Prepared by Montfort Mlachila and Brieuc Monfort.

${ }^{2}$ Paraguay is the fourth largest soy exporter in the world and a growing meat exporter.
} 
Figure 1. Paraguay: GDP Growth, Investment, and Output Gap

GDP Growth by Sector of Activity, 1995-2008

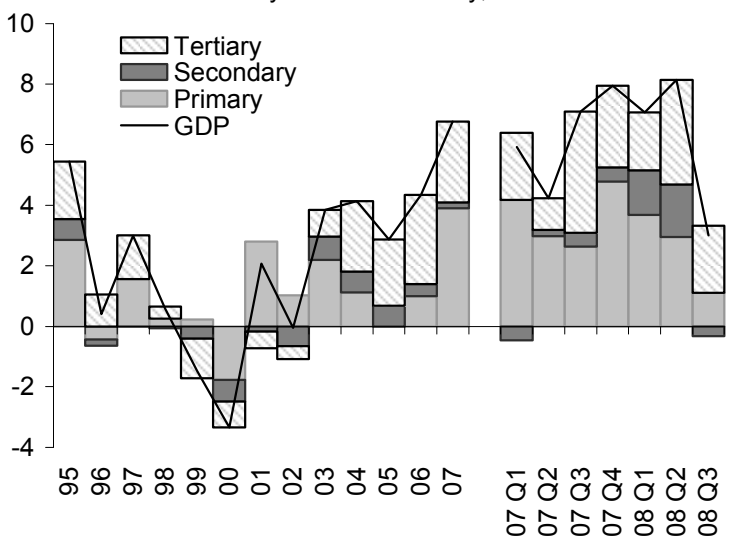

GDP, Primary GDP and Non-primary GDP Growth

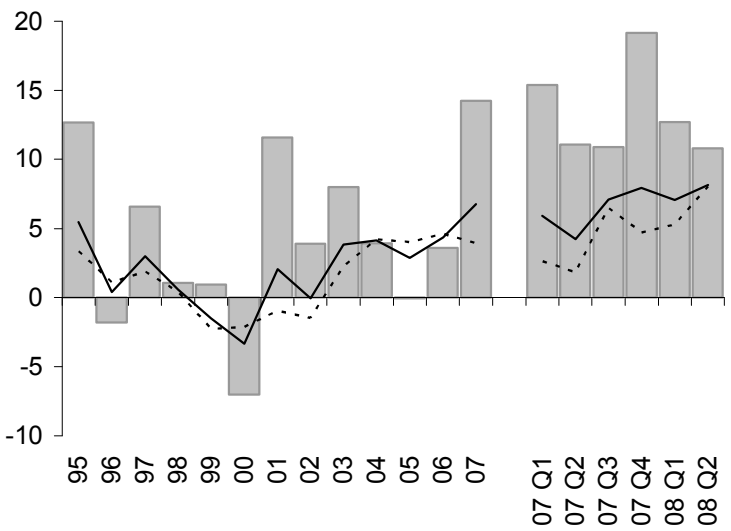

GDP Growth by Activity, 1995-2008 1/

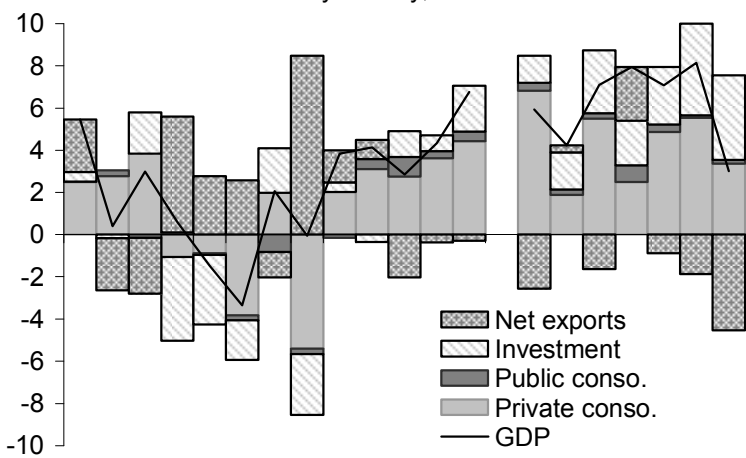

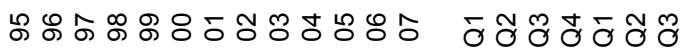

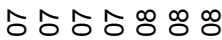

Investment Rate (Real GDP)

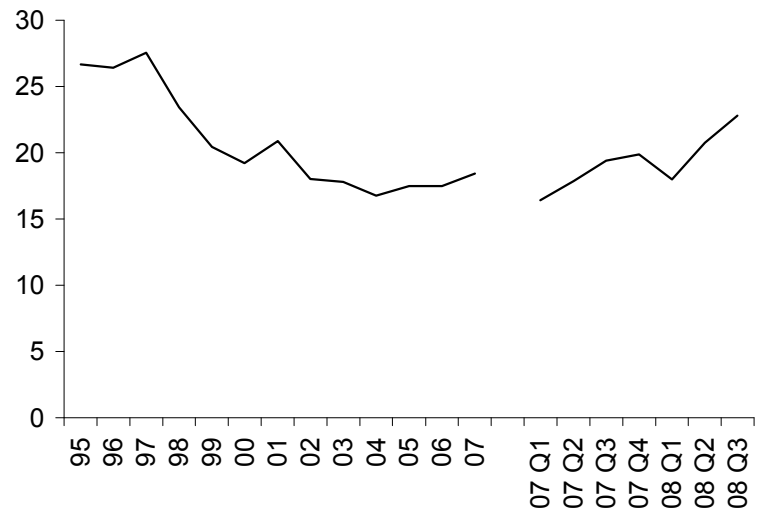

Different Measures of Output Gap

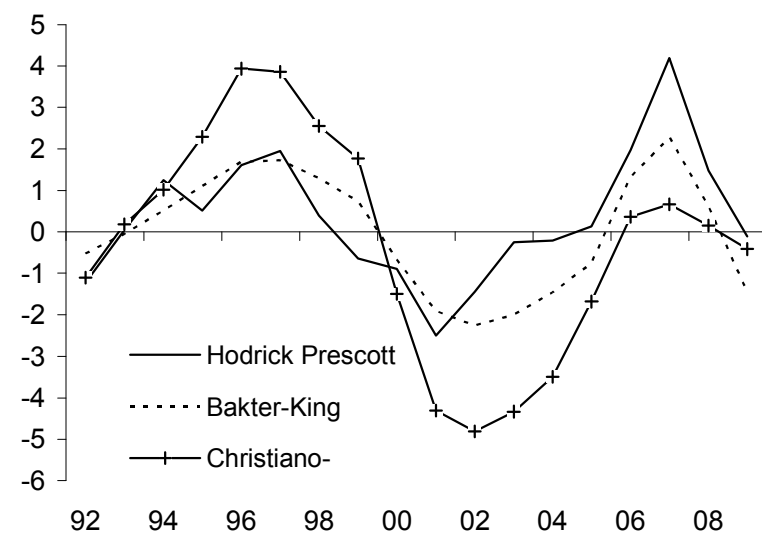

Potential Growth Using a Production Function

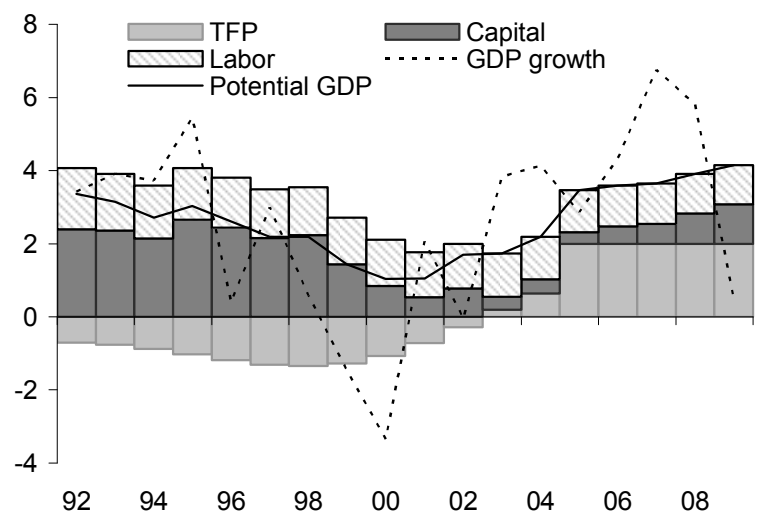

1/ 2008Q3 extrapolated using IMAEP data. 


\section{The contribution of the primary sector to the economy has been uneven and} volatile during the period. Adverse climatic conditions depressed agricultural production during 2004-06, but the significant investment realized during the period contributed to record productions in 2007 and 2008 (with agriculture growing at 24 percent in 2007, and $10 \frac{1}{2}$ percent in 2008). In the same way, the livestock and meat production sector has registered an annual average growth rate of 9 percent in 2004-2006, before contracting in 2007 , and recovering in 2008. Overall, the primary sector has contributed $1 / 3$ to growth rate of total GDP during 2003-2008. During 2007-08, its contribution to GDP growth increased to half. In this context, traditional measures of the business cycle might be biased upward, confusing the long-lasting effect of a positive terms-of-trade shock, which is currently being reversed, with a permanent increase of potential growth.

5. Most indicators point to a positive output gap in 2007 and 2008 (Table 1). The results on total GDP with a Hodrick-Prescott filter suggest a growing positive output gap of 2 percent in 2007 , closing in 2008, and shifting to a negative gap of $1 \frac{1}{2}$ percent for 2009 . The results are only modified at the margin when using non-agriculture GDP. They suggest a smaller deviation in 2007, but also a somewhat smaller negative gap for 2009. Other statistical indicators follow broadly similar trends, but with a cyclicality somewhat muted. Finally, a production function suggests that the excess output gap continued to increase in 2008 , before declining in 2009. In the rest of the paper, we use the output gap derived from the Hodrick-Prescott filter.

Table 1. Paraguay: Different Measures of Output Gap

\begin{tabular}{|c|c|c|c|c|c|c|c|c|}
\hline & \multicolumn{4}{|c|}{ Annual data } & \multicolumn{4}{|c|}{ Quarterly data } \\
\hline & 2006 & 2007 & 2008 & 2009 & 2006 & 2007 & 2008 & 2009 \\
\hline \multicolumn{9}{|l|}{ Total GDP } \\
\hline \multicolumn{9}{|l|}{ Statistical filters } \\
\hline Hodrick Prescott & 2.0 & 4.2 & 1.5 & -0.1 & 1.6 & 2.5 & 0.0 & -1.3 \\
\hline Christiano-Fitzgerald & 0.4 & 0.7 & 0.2 & -0.4 & 0.3 & 0.9 & -0.2 & $\ldots$ \\
\hline Baxter and King & 1.3 & 2.3 & 0.6 & -1.5 & 0.6 & 1.4 & -0.3 & $\ldots$ \\
\hline \multicolumn{9}{|l|}{ Production function } \\
\hline Productivity at $2.5 \%$ & -2.3 & 0.2 & 1.5 & -2.5 & $\ldots$ & $\ldots$ & $\ldots$ & $\ldots$ \\
\hline Productivity at $2 \%$ & -1.3 & 1.7 & 3.5 & -0.1 & $\ldots$ & $\ldots$ & $\ldots$ & $\ldots$ \\
\hline \multicolumn{9}{|l|}{ Non agricultural GDP } \\
\hline \multicolumn{9}{|l|}{ Statistical filters } \\
\hline Hodrick Prescott & 1.6 & 3.2 & 1.0 & -0.2 & 1.2 & 1.9 & -0.1 & -1.1 \\
\hline Christiano-Fitzgerald & 0.3 & 0.5 & 0.1 & -0.4 & 0.0 & 1.2 & -0.3 & 0.0 \\
\hline Baxter and King & 1.2 & 1.5 & 0.3 & -1.5 & 0.0 & 0.8 & $-0.2 \ldots$ & \\
\hline
\end{tabular}

Source: Staff estimates. 


\section{Assessing Monetary Policy}

\section{Negative supply shocks and the economic slowdown should continue to exert} downward pressures on inflation. Since December 2008 core inflation has been within the official target band of the central bank. The negative supply shocks-especially the sharp decline in international commodity prices - combined with the sharp slowdown of the economy should put inflation on a firmly declining trend. In these conditions, it would seem appropriate to continue with the accommodative stance implemented since the summer of 2008.

7. Earlier research has shown that over the past fifteen years, monetary policy was guided more by "fear of floating" considerations than by inflation or output gaps. Monfort and Santos (2007) tried to characterize monetary policy over 1994-2006 by estimating different Taylor-augmented rules. They found that monetary policy was guided mainly by "fear of floating" considerations, with a focus on reserve loss and currency depreciation, rather than on the output gap. They also suggested, however, that at the end of their sample period, the monetary authorities seem to have been more responsive to inflationary pressures, but this effect was not captured in the regressions.

8. With the stabilization of the economy since 2003, the focus of monetary policy seems to have shifted to domestic factors. A quick examination of the data since 2003 suggests indeed that monetary policy has been more responsive to inflation than before (Figure 2) with the two tightening periods related to upticks in core inflation. By contrast, the earlier period shows sharp spikes in policy interest rate unrelated to inflation developments. A number of factors might explain why the focus of monetary policy has shifted from external to domestic variables over the recent period:

- $\quad$ The economy stabilized around 2003: after a large devaluation following the 2002 Argentinean crisis, the guarani started to appreciate, supported by better domestic and external fundamentals. The appreciation of the currency helped ensure financial stability in a highly dollarized economy.

- $\quad$ The Duarte Frutos administration made macroeconomic stability one of its priorities. This was particularly remarkable concerning fiscal consolidation, where, despite a high turnover at the Ministry of Finance, consecutive ministers pursued consistently a prudent fiscal policy, contributing to a declining in the debt to GDP ratio from 72 percent in 2002 to 19 percent in 2008. The authorities' programs were supported by two subsequent stand-by arrangements with the IMF (2003-2008). 
Figure 2: Paraguay: Monetary Policy Rules

Inflation and Depreciation, 2003-08

(Year-on-year)
Inflation and Policy Interest Rate, 2003-08

(Year-on-year)
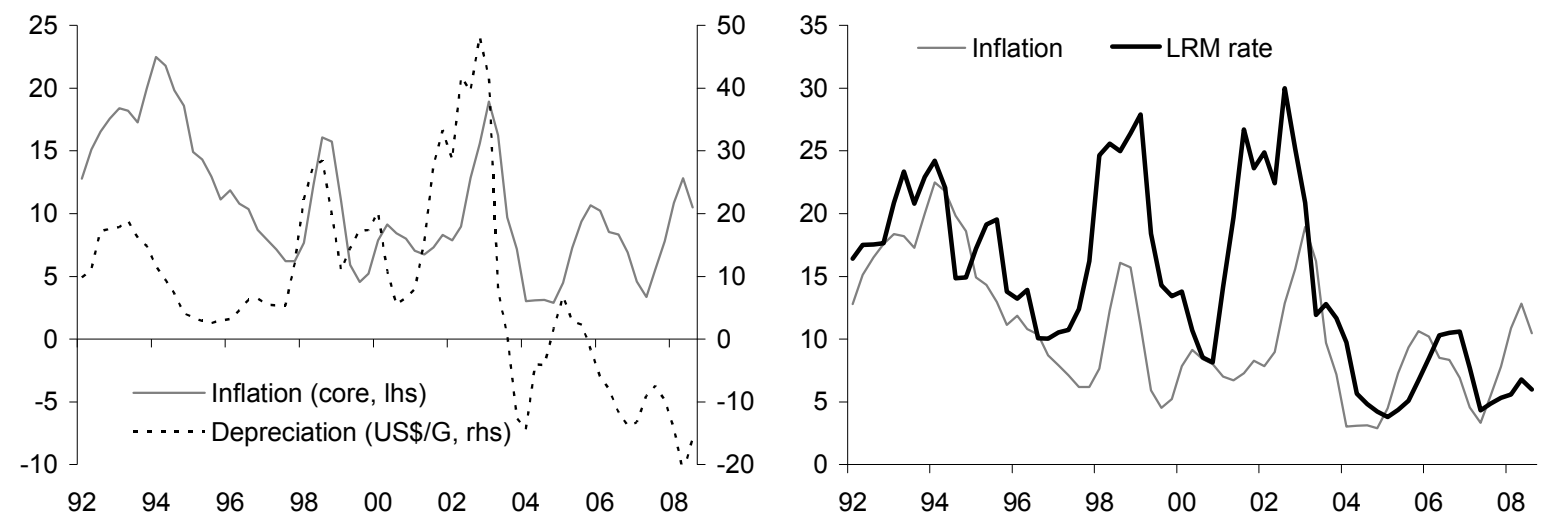

Inflation Target and Different Measures of Inflation

Deviation from Real Interest Rate Rule with one Lag 1/
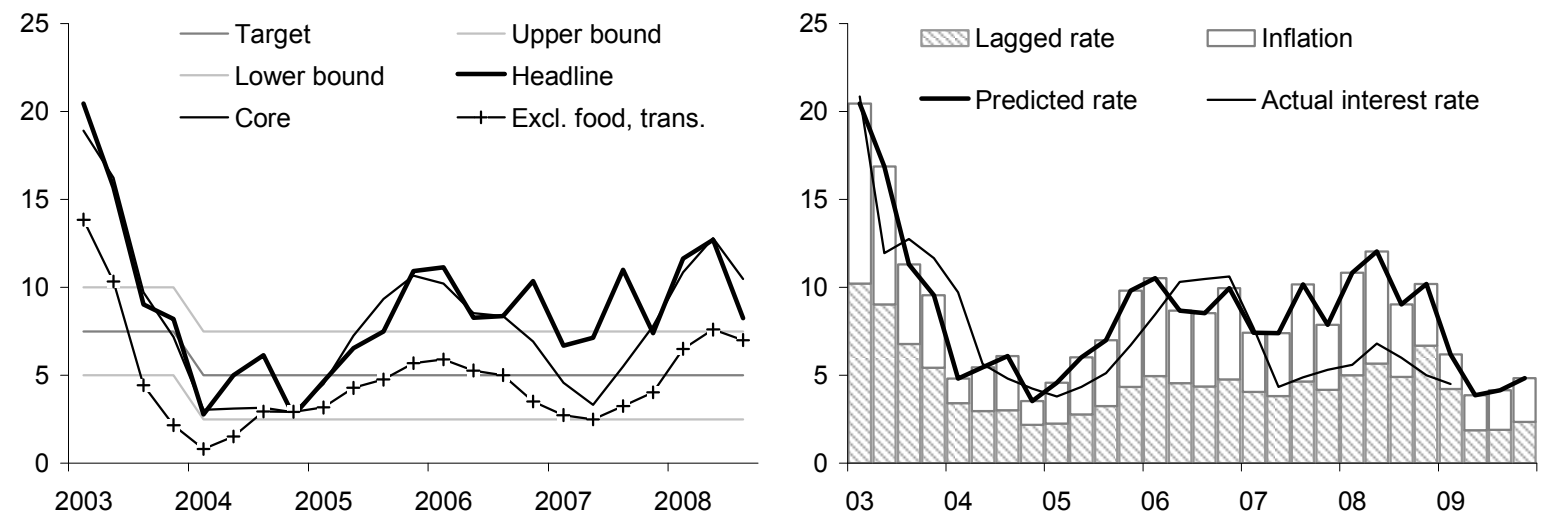

Deviation from Classic Taylor Rule 1/

Deviation from Taylor Rule with one Lag 1/
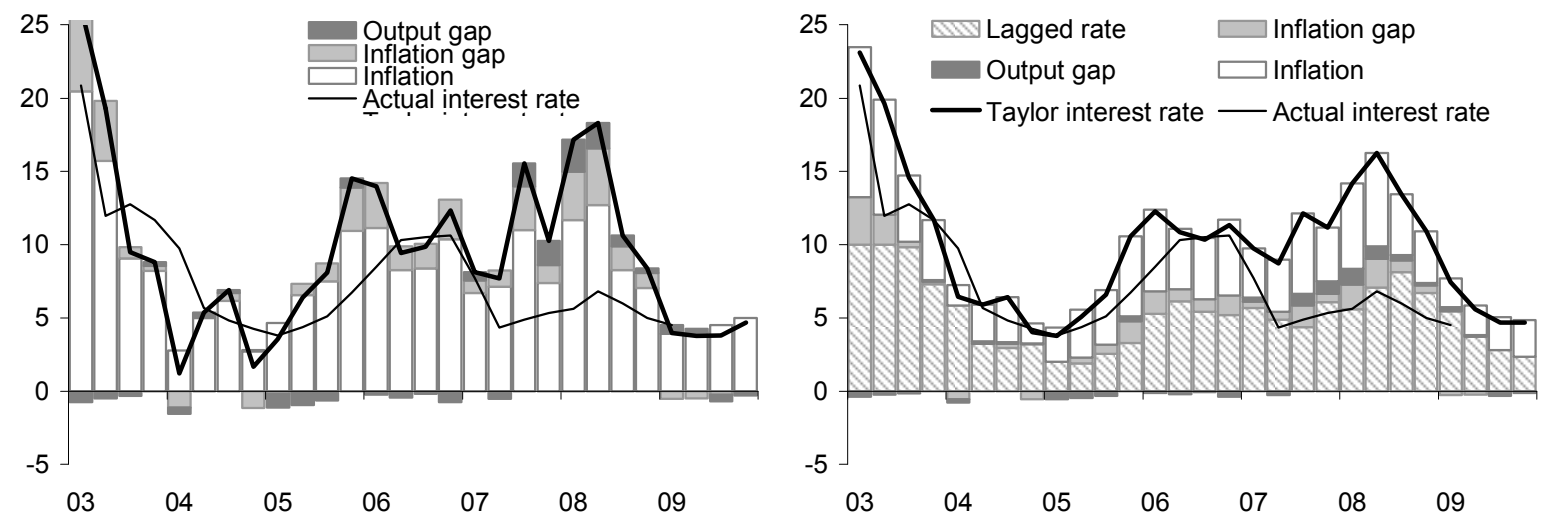

1/ For 2008Q4 to 2009, we compute the interest rate predicted by the rule, based on the following assumptions:the inflation is assumed to converge to 5 percent by end-2009, while a small negative output gap is gradually emerging. 
- The monetary authorities also implemented steps toward inflation-targeting, although inflation remained one of the many objectives of monetary policy, and the different central bank governors have weighted differently these conflicting objectives. ${ }^{3}$ The central bank started announcing an end-year target for inflation with a broad band of $+/-2.5$ percentage points, first set at 71/2 percent in 2003, and thereafter at 5 percent. Communication on inflation was also increased, with a monthly press briefing on inflation.

\section{To derive some insights about past and future monetary policy, we use ad-hoc} monetary policy rules. Unlike in earlier work, we do not attempt to estimate monetary policy rules, an effort which might be defeated anyway by the short time span - although covering two full monetary policy cycles - and the change of emphasis of different central bank governors. Instead, we try to derive insights from comparing the actual interest rate 4 from the interest rate predicted by ad-hoc monetary policy rules. While we do not claim that these rules would have been optimal for Paraguay, it is reasonable to assume that in the stabilized post-2003 environment, considerations about inflation and output gap should have been central to monetary policy decision making. We study four different monetary rules:

- Taylor rule: in the classic Taylor (1993) rule, the nominal interest rate is determined as the sum of neutral long-term real interest rate and the inflation rate, augmented by deviations from the inflation objective and the output gap. The coefficient of both the inflation gap and output gap are assumed to be $1 / 2$ in the original Taylor paper, although we explore the impact of alternative weights. The rule can be specified as follows:

$$
\mathrm{r}=\Delta \mathrm{p}+\rho+\alpha\left(\Delta \mathrm{p}-\Delta \mathrm{p}^{*}\right)+\beta\left(\mathrm{y}-\mathrm{y}^{*}\right)
$$

with $\rho$ the neutral real interest rate, $\Delta \mathrm{p}^{*}$ the inflation objective, and $\mathrm{y}-\mathrm{y}^{*}$ the output gap.

- $\quad$ Real interest rate rule: this is a specific case of the rule above, with no weights on the inflation gap and output gap.

- Augmented monetary rules with one lag. In both cases, we augment the baseline rule by adding a lag interest rate to account for inertia in interest rate:

\footnotetext{
${ }^{3}$ Since 2003, the central bank has had four governors.

${ }^{4}$ The policy interest rate is given by the weighted average rate on sterilization paper (Letras de Regulación Monetaria).
} 


$$
\mathrm{r}=\gamma \mathrm{r}(-1)+(1-\gamma)\left(\Delta \mathrm{p}+\rho+\alpha\left(\Delta \mathrm{p}-\Delta \mathrm{p}^{*}\right)+\beta\left(\mathrm{y}-\mathrm{y}^{*}\right)\right)
$$

with $\gamma$ the lagged coefficient, set at $1 / 2$ for simplicity ${ }^{5}$.

10. We study the performance of the rule for different target inflation rates. The target rate of inflation shifted from headline inflation to core inflation in 2008, when large swings of the volatile components of the headline index eroded the relevance of this index as a policy objective. ${ }^{6}$ In addition, since one can consider the world food and energy shocks of 2008 as exogenous, we also present an inflation index excluding food and transport.

11. Results suggest that some form of Taylor rule captures the behavior of monetary policy rate during the period. Table 2 presents the root mean square error (RMSE) between the predicted policy rate and the actual rate; a lower RMSE indicates a better fit of the model. Rules with lagged interest rate perform in general better than rules with only contemporaneous variables. Thus monetary policy is best captured by a simple real interest rule with lag. Adding inflation and output gap tend to increase the RMSE, and all the more so when the reactivity of the central bank to deviation of inflation is increased. ${ }^{7}$ By contrast, until early 2007, a Taylor rule with a higher response to deviation from the output gap performs slightly better than a classic Taylor rule. From mid-2007, all models on headline or core inflation perform worse than earlier. The only exception is a model with inflation target measured by non-food, non transport inflation, although in these cases adding deviation for inflation or output tend to worsen the RMSE.

\footnotetext{
${ }^{5}$ Monfort and Santos (2006) find an autoregressive coefficient of 0.80 for Paraguay for 1994-2006, but between 0.33 and 0.92 for a sample of other dollarized economies in Latin America.

${ }^{6}$ Core inflation excludes fruits and vegetables, which represent 5.2 percent of the CPI index. Large variations of these items led to change of the year-on-year headline inflation rate by as much as 4.5 percentage points, in November 2007, when inflation decline from 12 percent to 7.4 percent, before declined to 6 percent in December. By contrast, core inflation was showing a steady increase.

${ }^{7}$ In the classic Taylor rule, the coefficient on the inflation gap is only 0.5 . A monetary policy reacting strongly to inflation gap would require a coefficient larger than 1.
} 
Table 2: Testing Different Monetary Rules in Paraguay, 2003-08

(Root mean square error of monetary policy rule to actual interest rate) $1 /$

\begin{tabular}{|c|c|c|c|c|c|c|c|c|c|}
\hline \multirow{3}{*}{$\begin{array}{l}\text { Target } \\
\text { From } \\
\text { To }\end{array}$} & \multicolumn{3}{|c|}{ Headline inflation } & \multicolumn{3}{|c|}{ Core inflation } & \multicolumn{3}{|c|}{ Non food non energy inf. } \\
\hline & 03Q1 & 03Q1 & 07Q2 & $03 Q 1$ & 03Q1 & 07Q2 & 03Q1 & 03Q1 & 07Q2 \\
\hline & 08Q3 & 07Q1 & 08Q3 & 08Q3 & 07Q1 & 08Q3 & 08Q3 & 07Q1 & 08Q3 \\
\hline \multicolumn{10}{|l|}{ Taylor rule } \\
\hline Real interest rate rule & 3.3 & 2.9 & 4.3 & 3.3 & 3.4 & 3.5 & 3.1 & 3.3 & 2.5 \\
\hline \multicolumn{10}{|l|}{ Taylor rule } \\
\hline$\alpha=0.5, \beta=0.5$ & 5.4 & 4.1 & 7.9 & 5.1 & 4.4 & 6.9 & 4.1 & 4.2 & 4.0 \\
\hline$\alpha=1, \beta=0.5$ & 7.5 & 5.6 & 10.5 & 7.0 & 5.9 & 9.2 & 5.0 & 5.2 & 4.7 \\
\hline$\alpha=.5, \beta=1$ & 5.8 & 4.1 & 9.0 & 5.5 & 4.4 & 8.0 & 4.5 & 4.3 & 5.1 \\
\hline \multicolumn{10}{|l|}{ Taylor rule with a lag } \\
\hline Real interest rate rule & 2.5 & 2.0 & 3.6 & 2.2 & 2.1 & 2.4 & 2.2 & 2.2 & 1.9 \\
\hline \multicolumn{10}{|l|}{ Augmented Taylor rule } \\
\hline$\alpha=0.5, \beta=0.5$ & 4.1 & 2.7 & 6.7 & 3.5 & 2.9 & 5.0 & 2.7 & 2.7 & 2.8 \\
\hline$\alpha=1, \beta=0.5$ & 5.7 & 3.8 & 9.0 & 4.9 & 4.0 & 6.8 & 3.3 & 3.4 & 3.2 \\
\hline$\alpha=.5, \beta=1$ & 4.4 & 2.6 & 7.5 & 3.8 & 2.8 & 5.9 & 3.0 & 2.8 & 3.7 \\
\hline \multicolumn{10}{|l|}{ Memorandum } \\
\hline Real interest rate premium $(\rho)$ & 0.0 & 0.0 & 0.0 & 0.0 & 0.0 & 0.0 & 3.0 & 3.0 & 3.0 \\
\hline
\end{tabular}

Source: Staff estimates.

1/ The table presents the RMSE of different policy rules, with the error measured as the deviation between the actual interest rate and the interest rate predicted by the rule.

Real interest rate rule: $r=\Delta p+\rho$

Taylor rule: $r=\Delta \mathrm{p}+\rho+\alpha\left(\Delta \mathrm{p}-\Delta \mathrm{p}^{*}\right)+\beta\left(\mathrm{y}-\mathrm{y}^{*}\right)$

Augmented Taylor rule: $r=\gamma \mathrm{r}(-1)+(1-\gamma)\left(\Delta \mathrm{p}+\rho+\alpha\left(\Delta \mathrm{p}-\Delta \mathrm{p}^{*}\right)+\beta\left(\mathrm{y}-\mathrm{y}^{*}\right)\right)$

The real interest rate premium is chosen as the average real interest rate for the period or as zero if negative. The real interest rule can be interpreted as a Taylor rule with $\alpha=\beta=0$.

12. Two complementary explanations could explain the large deviation between actual and predicated interest rates since 2007. One is related to the targeted rate of inflation, and the other to the level of the target itself.

- The monetary authorities decided to accommodate the impact of supply shocks on inflation. While the rule using the inflation target excluding products affected by supply shocks vindicates this approach, it is important to note that this inflation indicator rose 5.1 percentage points until mid-2008, but the policy rate increased only 2.7 percentage points. In addition, permanent deviations on headline inflation are expected to translate into higher narrower inflation index, due to the wage-indexation mechanism. ${ }^{8}$

\footnotetext{
${ }^{8}$ As stipulated by law, a council comprising representative of workers, employers, and the government, is summoned to decide on an adjustment whenever the cumulative rise of the cost of living since the previous adjustment surpasses 10 percent. The resulting wage adjustment is determined by negotiation and has historically often surpassed 10 percent. See Monfort and Pena (2008) for an analysis on inflation determinants in Paraguay.
} 
- $\quad$ The monetary authorities in fact tolerated higher inflation rate than the official target. Inverting the ad-hoc real interest rules to deduce the implicit inflation target gives a target higher by about 4 percentage points. Since the Taylor rule also imposed a penalty on positive output gap and as the economy was above potential, the target consistent with a Taylor rule would be around 7 percentage points. The initial reduction of interest rate in early 2007 was consistent with declining core inflation rates, but the monetary tightening in response to growing inflation rates-even measured on the narrower basket - and positive output gap, was much more moderate than the response predicted by any rule. ${ }^{9}$

13. The target interest rate predicted by different rules one-year ahead is only 150 to 250 basis points below the current rate. To assess the future path of interest rate, we take the output gap as derived from the models in the previous sections and assume a linear path for inflation to a target of about 5 percent by end-2009 (Table 3). ${ }^{10}$ The rule suggests that downward supply and demand shocks on inflation, combined with the output gap turning negative, should allow a reduction of interest rate. The different rules suggest that interest rates could be reduced by $200-800$ basis points, from the current level of the interest rate.

\section{One limitation of this exercise is that it does not integrate the impact of financial}

stress on the economy. In an environment marked by shocks that are affecting financial stability, this might call for larger interest rate declines than warranted by purely negative economic shocks. Taking into account financial factors would also have called for tighter monetary policy earlier, so as not to feed the high rate of credit growth in the range of 60-70 percent observed during the first part of 2008. In addition, the case for a sharp loosening of monetary policy in response to financial stress is not so clear-cut in the case of a dollarized economy as Paraguay. Monetary loosening to support bank balance sheets could backfire if an injection of liquidity produces a depreciation of the guaraní, at the risk of encouraging re-dollarization, ultimately forcing the monetary authorities to reverse the reduction of the interest rate to support the currency.

\footnotetext{
${ }^{9}$ The decline of policy interest rate by 500 basis points in March 2007 was justified as a technical change in the market of sterilization paper. Subsequent discussions of monetary policy in the Informe Economico published by the BCP gave a preeminent role to the market of sterilization paper, and less so to inflation. Concerns about the central bank balance sheet or about channeling credit to the economy seem to have been prevailed over concerns about inflation.

${ }^{10}$ This is a normative path. It would be consistent with a scenario where possible pressures from imported inflation are broadly balanced by downward pressures arising from supply and demand shocks. It also assume that the current loosed stance of monetary policy have not contributed to anchoring a higher rate of inflation.
} 
Table 3. Future Path of Interest RateS, 2008Q4-2009Q4

\begin{tabular}{|c|c|c|c|c|}
\hline & \multicolumn{2}{|c|}{ Predicted } & \multicolumn{2}{|c|}{ Decline } \\
\hline & $\overline{2008 Q 42}$ & Q4 & $\begin{array}{l}\text { Predicted } \\
\text { to predicted }\end{array}$ & $\begin{array}{r}\text { Actual } \\
\text { to predicted }\end{array}$ \\
\hline \multicolumn{5}{|l|}{ Without lag } \\
\hline Real IR rule & 7.0 & 5.0 & 2.0 & 0.0 \\
\hline Taylor rule & 10.9 & 4.7 & 6.2 & 0.3 \\
\hline \multicolumn{5}{|l|}{ With lag } \\
\hline Real IR rule & 13.4 & 5.0 & 8.4 & 0.0 \\
\hline Taylor rule & 8.4 & 4.7 & 3.7 & 0.3 \\
\hline Actual rate & 5.0 & & & \\
\hline
\end{tabular}

Source: Staff estimates.

\section{Assessing the Need for Fiscal Stimulus}

\section{General Considerations}

\section{This section assesses the need for fiscal stimulus given that output in 2009 is} projected to grow well below target. To answer the question analytically, it is important to clarify a number of concepts used to assess fiscal policy. The concept of fiscal stance refers to how the current fiscal position relates to the fiscal position when the economy is growing close to potential (Chalk 2001). It is a useful concept when assessing fiscal policy when the economy is growing above or below potential. To derive the fiscal stance, one needs the concept of neutral fiscal balance $(N B)$ which is given as:

$$
\begin{aligned}
& N B=\tau Y-\gamma Y^{*} \\
& \text { Where } Y=\text { actual output } \\
& \qquad \begin{array}{l}
Y^{*}=\text { potential output } \\
\tau=\text { revenue-to-GDP ratio at some base period } \\
\gamma=\text { expenditure-to-GDP ratio at some base period }
\end{array}
\end{aligned}
$$

The fiscal stance $(F S)$ is the difference between the neutral fiscal balance and the actual fiscal balance $(F B)$ :

$$
\begin{gathered}
F S=N B-F B=\left(\tau Y-\gamma Y^{*}\right)-(T-G) \\
\text { Where } T=\text { actual revenue } \\
\mathrm{G}=\text { actual expenditure }
\end{gathered}
$$

The fiscal impulse, which is often the preferred measure of fiscal policy, is given as the change in the fiscal stance. It is preferable to use this concept because it is less conditioned by the choice of base period.

$F I=\Delta F S$ 


\section{One of the most commonly used measures of fiscal policy is the structural}

balance $(\boldsymbol{S B})$. It shows what would be the fiscal position if the economy were growing at close to potential. As argued by Chalk (2001), it provides a better indicator of discretionary fiscal policy than the change in the primary balance and that it is a particularly good indicator of the demand stimulus arising from changes in the fiscal position. It is given by:

$$
S B=T\left(\frac{Y_{t}^{*}}{Y_{t}}\right)^{\varepsilon}\left(\frac{Y_{t-1}^{*}}{Y_{t-1}}\right)^{\text {slag }}-\left(G+U B\left(\frac{U^{*}-U}{U}\right)\right)
$$

Where $U^{*}=$ natural rate of unemployment

$U=$ actual rate of unemployment

$\varepsilon$, elag $=$ elasticities

$U B=$ unemployment benefits

As highlighted by Chalk, the structural balance is a good indicator of the change in discretionary fiscal policy if the fiscal position is little affected by exogenous factors such as exchange rates, interest rates, oil prices, etc. In the case of Paraguay, these factors are particularly important as shown in Monfort and Santos (2007), so one should be careful in interpreting the results of structural balance calculations.

\section{The Paraguayan Case}

\section{The need for, and efficacy of, fiscal discretionary fiscal policy varies widely} according to the country context. In most developed countries, when there is a recession, lower tax revenues, combined with higher unemployment benefits, $U B$, can play the role of powerful automatic stabilizers. In countries such as Paraguay, the effect of automatic stabilizers is reduced because there are no employment benefits. This generally implies that the role of discretionary fiscal policy is more important than in developed countries.

\section{Fiscal policy in Paraguay over the past five years has generally been counter-} cyclical (Figure 3). The fiscal stance has been contractionary, given that output was growing above potential, especially over the past two years. As a result, movements in the actual balance generally followed that of the structural balance (Figure 4). Going forward, there is need to project a reasonable fiscal stance that could mitigate the effects of the deceleration while maintaining a favorable debt position. However, estimating the impact of fiscal policy on aggregate demand is far from easy as shown by IMF (2008), as there is no consensus on how to compute impact multipliers. ${ }^{11}$

\footnotetext{
${ }^{11}$ See for instance, Hemming et al. (2002), who, in an extensive review of the literature, conclude that fiscal multipliers are overwhelmingly positive but small, on the order of $03 .-0.7$, for $\mathrm{G} 7$ countries..
} 
Figure 3. Paraguay: Fiscal Impulse, 1990-2009

Fiscal Balance and Primary Fiscal Balance (In percentage of GDP)

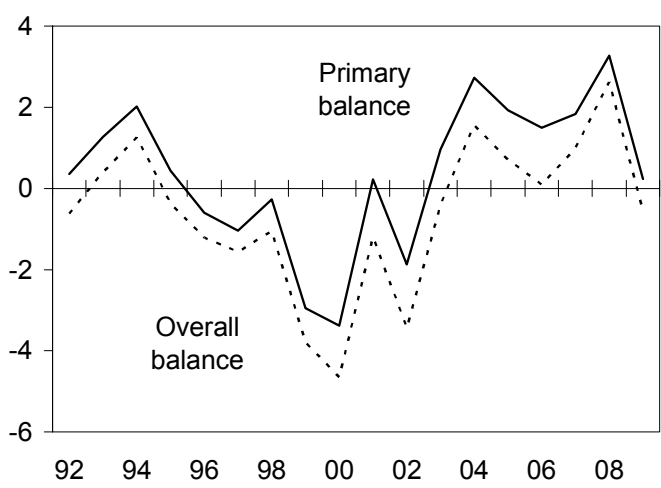

Revenues and Primary Expenditure (In percentage of GDP)

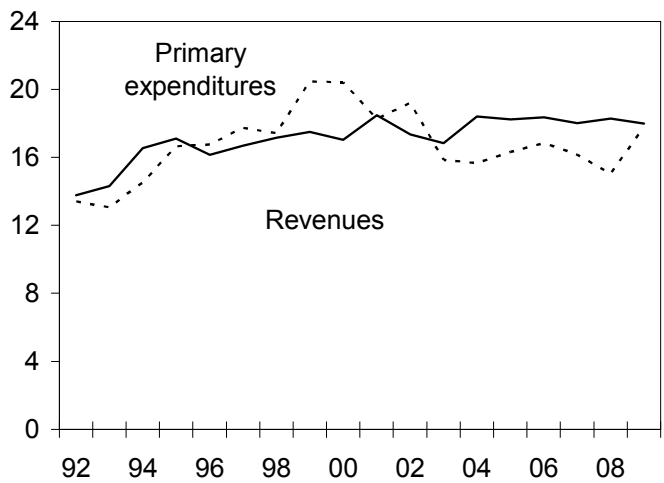

Real GDP Growth and Output Gap (Annual percentage change and deviation)

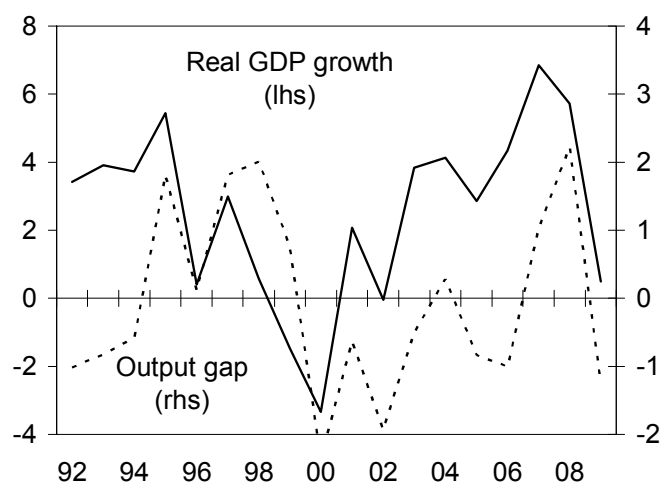

Fiscal Stance, Fiscal Impulse and Output Gap (Base year 1994)

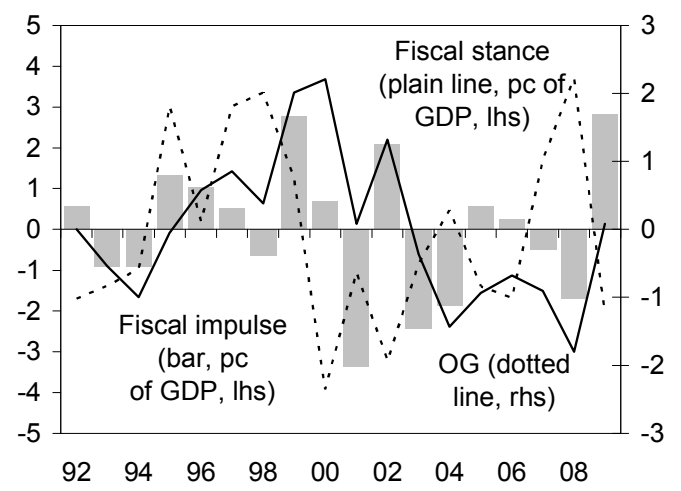

19. Generally, if an economy is stuck in an inefficient (low-level) equilibrium, an increase in aggregate expenditure is useful in increasing aggregate demand. ${ }^{12}$ However, the ultimate impact can vary widely depending on a number of issues, including: (i) the policy instrument used; (ii) the degree of monetary policy accommodation; and (iii) the openness of the economy. Using the traditional Keynesian multiplier, the overall increase in aggregate demand for a given change in expenditures is given as:

$\Delta Y=k_{G} \Delta G$

$$
\text { Where: } k_{G}=\frac{1}{1-c(1-\tau)+m}
$$

\footnotetext{
${ }^{12}$ In a neo-classical model with perfect competition, fiscal policy has limited effects through the demand side as Ricardian effects dominate, i.e., an increase in the deficit leads to increased savings as economic agents expect that their future tax liabilities will increase.
} 


$$
\begin{aligned}
& c=\text { marginal propensity to consume } \\
& m=\text { marginal propensity to consume }
\end{aligned}
$$

20. There is need to be conservative in applying multipliers. In Paraguay, a calibration of the multipliers using historical values of the parameter shows that the impact of a change in the fiscal position on aggregate demand is of the order of 1.1. Given all the uncertainties, it may be appropriate to err on the side of caution, and assume a lower multiplier of around 0.80.9. An increase in expenditures on the order of 1 1 $1 / 2-2$ percent of GDP, as projected in 2009 could improve GDP growth by about $1 \frac{1}{2}$ percentage points. A structural balance of the order $-1 \frac{1}{2}$ percent of GDP in 2009 would be broadly appropriate.

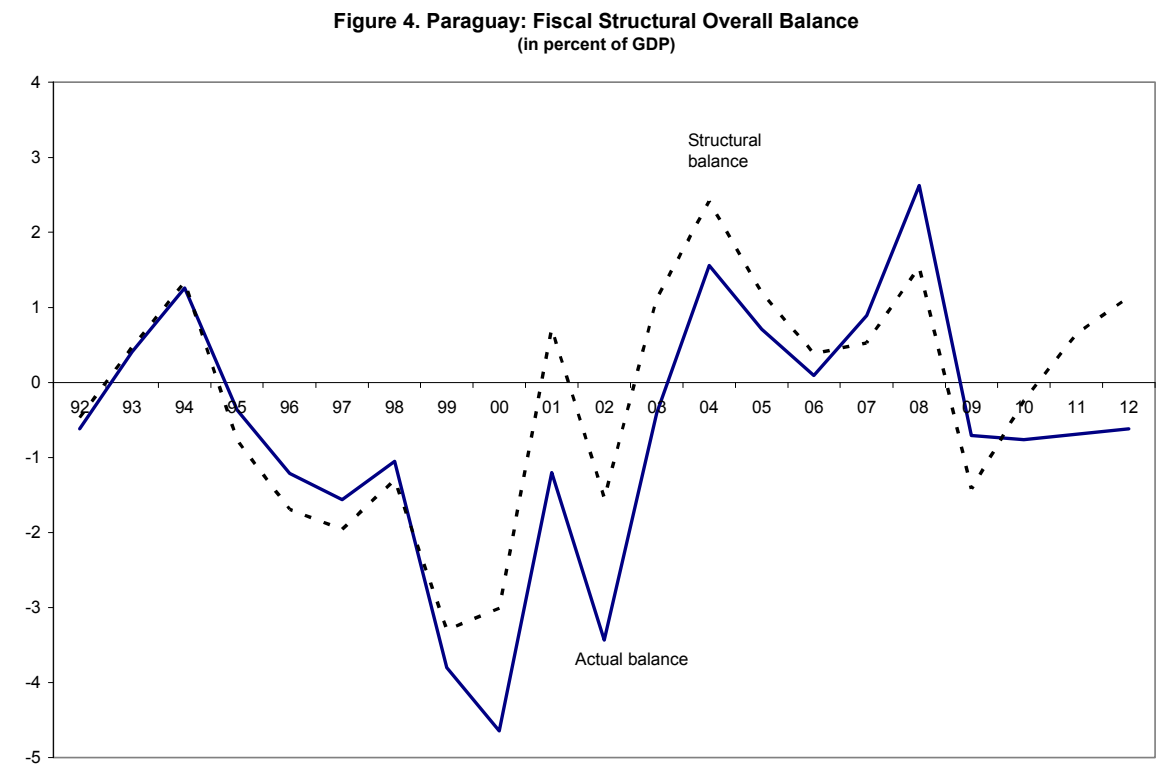

\section{E. Concluding Remarks}

\section{This paper has performed a forward-looking assessment of monetary and fiscal} policies against the background of the global economic crisis. The main finding is that accommodative monetary and fiscal policies in the current conjuncture are broadly appropriate. Given the current state of the economy in terms of the business cycle, the application of various monetary policy rules shows that the current level of interest rates, although rather low, is broadly appropriate. Nonetheless, given that Paraguay is a dollarized economy, care should be taken to avoid excessive loosening as this could lead to increased exchange rate risks. The loosening of fiscal policy should compliment the monetary accommodation. As the authorities have been implementing broadly counter-cyclical fiscal policies over the past five years, which have allowed a sharp decline in public debt levels, they are in a relatively strong position to have a significant fiscal stimulus (about 3 percent of GDP) and a structural deficit of $1-1 \frac{1}{2}$ percent of GDP. 


\section{REFERENCES}

Chalk, N.A., 2001, "Structural Balances and All That: Which Indicators to Use in Assessing Fiscal Policy?” IMF Working Paper 01/101 (Washington DC: International Monetary Fund).

Hemming, R., M. Kell, and S. Mahfouz, 2002, "The Effectiveness of Fiscal Policy in Stimulating Economic Activity-A Review of the Literature," IMF Working Paper 02/208 (Washington DC: International Monetary Fund).

IMF, 2008, "Fiscal Policy as a Countercyclical Tool," Fall World Economic Outlook, Chapter 5 (Washington DC: International Monetary Fund).

Monfort, B., and A. Santos, 2007, “Assessing Macroeconomic Policies,” IMF, Selected Issues Paper (Washington DC: International Monetary Fund). ., and S. Peña, 2008, "Inflation Determinants in Paraguay: Cost Push versus Demand Pull Factors," IMF Working Paper 08/270 (Washington DC: International Monetary Fund).

Taylor, J., 1993, “Discretion versus Policy Rules in Practice.” Carnegie-Rochester Conference Series on Public Policy 39, 195-214. 


\section{Post-Crisis Behavior of Banks in Mercosur ${ }^{1}$}

\section{A. Introduction}

\section{Most of the banking crisis literature has concentrated on the determinants of} systemic banking crises, rather than on the effects in terms of how banks behave. With the exception of studies such as Barajas and Steiner (2002), Demirgüç-Kunt et al. (2006a) and Dell'Ariccia et al. (2008), little attention has been given to the longer-term effect of crisis on the behavior of bank fundamentals, particularly credit supply. Even though the recovery of some bank functionality can be implicitly assumed to be part of the post crisis stabilization process, evidence of some protracted recovery exists particularly regarding patterns of intermediation (Demirgüç-Kunt et al. 2006a).

\section{This paper analyzes the post-crisis behavior of banks in the Mercosur ${ }^{2}-$ a region} that has witnessed a significant number of banking crises. It uses both aggregate and bank-level data during the period 1990-2006. The primarily focus is on credit supply (Table 1), but also it analyzes variables related to profitability, risk, and liquidity. The paper uses

convergence methodology — which is often used in the growth literature - to identify the evolution of bank behavior in the region after crises. To the best of our

\begin{tabular}{|c|c|c|c|c|c|c|c|c|}
\hline & \multicolumn{4}{|c|}{ Bank Credit } & \multirow{2}{*}{\multicolumn{2}{|c|}{$\begin{array}{l}\text { Demand- side factors } \\
\text { GDP growth Spread 5/ }\end{array}$}} & \multicolumn{2}{|c|}{ Supply-side factors } \\
\hline & $\begin{array}{r}\text { Total } \\
\text { credit } 1 /\end{array}$ & $\begin{array}{l}\text { Private } \\
\text { credit } 2 /\end{array}$ & $\begin{array}{r}\text { Public } \\
\text { credit 3/ }\end{array}$ & $\begin{array}{r}\text { Liquid } \\
\text { reserves } 4 /\end{array}$ & & & Deposits 6/ & Capital 7/ \\
\hline Argentina & 3.0 & -2.9 & 15.2 & 27.7 & 2.5 & 13.2 & 3.6 & 2.4 \\
\hline Brazil & 1.2 & -4.0 & 10.7 & 4.1 & 7.6 & -3.5 & 3.3 & 4.1 \\
\hline Paraguay & -3.1 & -3.4 & 17.2 & -0.2 & 2.3 & 10.3 & -2.3 & -1.0 \\
\hline Uruguay & -23.3 & -22.4 & -18.1 & 4.4 & 12.7 & -39.3 & -9.7 & -10.2 \\
\hline Average & -5.5 & -8.2 & 6.3 & 9.0 & 6.3 & -4.8 & -1.3 & -1.2 \\
\hline $\begin{array}{l}\text { Sources: Ban } \\
\text { 1/ Total credi } \\
\text { 2/ Credit prov } \\
\text { 3/ Credit prov } \\
\text { 4/ Ratio of liq } \\
\text { 5/ Intermedia } \\
\text { 6/ Ratio of de } \\
\text { 7/ Ratio of eq }\end{array}$ & $\begin{array}{l}\text { scope, IMF (IF } \\
\text { rovided by de } \\
\text { ed to the priv } \\
\text { ed to the pub } \\
\text { d reserves to } \\
\text { n spread (len } \\
\text { sits to asset } \\
\text { ty to assets o }\end{array}$ & $\begin{array}{l}\text { FS), and aut } \\
\text { leposit mone } \\
\text { vate sector b } \\
\text { olic sector by } \\
\text { GDP for de } \\
\text { nding rate-d } \\
\text { ts of deposit } \\
\text { of deposit m }\end{array}$ & $\begin{array}{l}\text { hors' calcula } \\
\text { y banks. } \\
\text { y deposit mo } \\
\text { deposit mor } \\
\text { posit money } \\
\text { posit rate). } \\
\text { money bank } \\
\text { ney banks. }\end{array}$ & $\begin{array}{l}\text { tions. } \\
\text { ney banks. } \\
\text { banks. } \\
\text { s. }\end{array}$ & & & & \\
\hline
\end{tabular}

knowledge, this is a novel approach in this area. An added advantage of using this approach over others currently used in the literature is that we can empirically quantify the rate of convergence and the institutional and macroeconomic factors that condition the convergence. Moreover, the methodology allows one to identify — in some hierarchical order - factors that condition this persistent deviation from "normality."

\footnotetext{
${ }^{1}$ Prepared by Montfort Mlachila. This paper is a condensed version of a working paper by Sanya and Mlachila, "Post-Crisis Bank Behavior: Lessons from Mercosur," forthcoming.

${ }^{2}$ Argentina, Brazil, Paraguay, and Uruguay.
} 
3. The main finding is that banks in the Mercosur exhibit two notable weaknesses: insufficient private sector intermediation and holding of high levels of excess liquidity. These relate to the long-run persistence of non-convergence toward comparator benchmarks only. For example, the paper shows that other bank fundamentals, such as capitalization, profitability and other measures of the risk profile of banks are similar to regional comparators and also to pre-crisis levels, and could support increased lending. These effects are more pronounced in domestic banks.

\section{B. Banking Crises in Mercosur}

\section{General Overview of Post-Crisis Banking Behavior}

4. There is a general consensus in the literature on leading indicators of banking crises. First, financial liberalization undertaken in conditions where financial institutions are underdeveloped, law enforcement is weak and regulatory supervision is inadequate can sow the seeds of a financial crisis (Hassan and Hussain 2006). Second, credit booms, if followed by weak and deteriorating economic fundamentals, can lead to weaknesses in bank balance sheets. Third, inconsistencies between fiscal and monetary policies and exchange rate commitments can lead to the simultaneous occurrence of currency and banking crises (Kaminsky and Reinhart 1999). Finally, speculative attacks on the currency, often combined with investor-herding behavior such as experienced in Argentina in 2001, deepens the crisis (Bleaney et al. 2008).

5. In the literature, the following types of post-crisis bank behavior have been typically reported:

- First, there is often a substantial decline in credit to the private sector which may be demand- or supply-related (Demirgüç-Kunt et al. 2006a and Dell'Arriccia et al. 2008). The financial accelerator effect, first proposed by Bernanke (1983), can explain, to some extent, the behavior of bank credit and its relationship with the persistence and amplitude of cyclical fluctuations in the economy.

- $\quad$ Second, there is a decline in bank profitability. The negative effect of crises on bank profitability is often linked to the high levels of non-performing loans on banks' balance sheets (Cardim de Carvalho 1998, Pangestu 2003).

- $\quad$ Third, an increase in intermediation spreads often ensues (Gupta 2005, Honohan 2005). The increase in spreads is synonymous with macroeconomic volatility that may occur at or around the same time as a banking crisis. This is persistent in countries with poor legal infrastructure, concentrated banking systems and continued macroeconomic uncertainty (Gelos 2006). 
- $\quad$ Fourth, increased dollarization follows banking crises. Since banking crises are typically accompanied by currency crises, depositors often lose faith in the local depreciating currency (De Nicoló et al. 2003).

\section{The Evolution of Bank Crises in Mercosur ${ }^{3}$}

\section{There are four main common causal factors of banking crises in the Mercosur} region (Table 2). These are financial liberalization without adequate prudential safeguards, significant exposure to government risk (with the exception of Uruguay), currency mismatches on banks' balance sheets, and contagion. Multiple factors often combined to increase the frequency, depth and cost of banking crises. These included sharp macroeconomic imbalances that weakened the operating capacity of the banking system, and inadequate regulatory and supervisory frameworks, allowing an incipient problem to reach systemic proportions. Furthermore, the interaction between currency pegs and banking stability proved to be significant in the Mercosur region in the 1990s as deposit runs provided the liquidity necessary for a successful speculative attack on the currency. Expected high returns from currency speculation may also have helped destabilize an otherwise stable banking system (Bleaney et al. 2008). According to Gourinchas et al. (2001), the effects of credit growth after financial liberalization made the economies in Latin America considerably more volatile and vulnerable to financial and balance of payments crises than other regions around the world.

\section{Methodology}

\section{The Concept of Convergence and Bank Behavior}

\section{To empirically analyze post crisis bank behavior, we use the concept of} convergence extensively used in the economic growth literature. For instance, Barro and Sala-i-Martin (1992) and Mankiw et al. (1992) use it to analyze how long it typically takes poor countries to "catch up" with rich countries in terms of per capita GDP. For convergence to occur, the measure of dispersion between countries should decrease over time. The growth rate and standard deviation form the basis for measuring the so-called $\sigma$-convergence in the growth literature. Therefore for countries to become similar over time the cross sectional standard deviation of their real per capita GDP should decrease over time (Salai-i-Martin 1996). We use a similar analogy to construct our measures of dispersion. In our study, postcrisis recovery will correspond, for instance, to a decrease in measures of deviation between current levels of credit supply and the specified benchmarks of normal levels of intermediation. Box 1 gives more details on the convergence and the empirical model.

\footnotetext{
${ }^{3}$ For a detailed description of individual cases, see Sanya and Mlachila (forthcoming).
} 


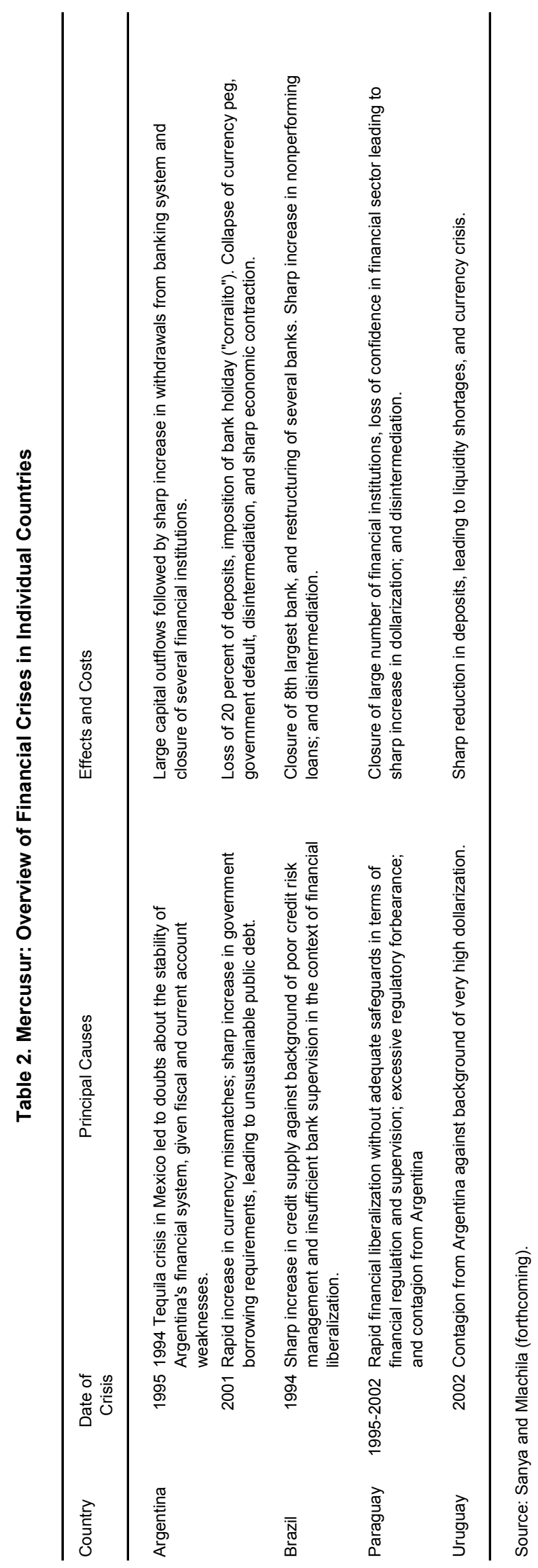




\section{Box 1. The Model}

We construct two measures of deviations of bank behavior from pre-crisis levels as follows:

$$
\begin{aligned}
& Y_{i j, t}=\ln \left(X_{i j, t} / \bar{X}_{i j}\right) \quad \text { for all } t>t_{0} \\
& D_{i j, t}=\ln \left(\left(X_{i j, t}-\bar{X}_{i j}\right) / \bar{X}_{i j}\right) \quad \text { for all } t>t_{0} \\
& \bar{X}_{i j}=\sum_{t=t_{0}-3}^{t_{0}-1} X_{i j, t} / 3
\end{aligned}
$$

$t_{0}$ is year of occurrence of systemic crisis, $X_{i j, t}$ is the post-crisis level of the variable of interest in bank $j$ in country $i$ at time $t$, and $\bar{X}_{i j}$, the benchmark, is calculated as the average of the three years before the onset of a crisis for each bank. We have chosen three years because a longer time series may reflect the effects of structural changes in the economy and banking system unrelated to the episode of distress, while a shorter time series would probably give too much weight to the most recent observations which may be too close to the crisis. Abnormal bank behavior is deemed to occur if $Y_{i j, t}$ and $D_{i j, t} \neq 0$.

Following the ideas in previous studies, we analyze two main concepts of convergence: $\beta$ - and $\sigma$-convergence. Convergence of the $\beta$-type considers whether the growth in bank fundamentals, e.g., credit supply, exhibits a negative correlation with its current levels. In other words, for the level of intermediation to converge back to its pre-crisis level, subsequent rates of growth will decline if the initial level is higher than the pre-crisis level and vice versa. Convergence of the $\sigma$-type means dispersion of between current levels and the benchmark decreases over time

Absolute convergence in our case implies growth rates $Y_{i j, t}$ are equal for all banks and the benchmark $\bar{X}_{i, j}$ is the same for all banks. In other words, the occurrence of crisis is the only reason why bank behavior deviates from a common benchmark. However, the conditions necessary for this assumption to be consistent are stringent and require all banks - or country-specific heterogeneity - to be captured by the benchmark. If this is not the case, factors that drive dispersion embedded in the error term may affect the estimates of $\alpha_{1}$ (Evans 1997). Since we do not want to be unduly constrained by this assumption, we also estimate conditional convergence. The regression equations of the test for absolute $\beta$ - and $\sigma$-convergence, respectively, have the following forms:

$$
\begin{aligned}
& Y_{i j, t}=\ln \left(X_{i j, t} / \bar{X}_{i j}\right)=\alpha_{0}{ }^{y}+\alpha_{1}{ }^{y} \ln \left(\bar{X}_{i j}\right)+\varepsilon_{i t}{ }^{y} \\
& D_{i j, t}=\ln \left(\left(X_{i j, t}-\bar{X}_{i j}\right) / \bar{X}_{i j}\right)=\alpha_{0}{ }^{d}+\alpha_{1}{ }^{d} \ln \left(\bar{X}_{i j}\right)+\varepsilon_{i t}{ }^{d}
\end{aligned}
$$

Absolute convergence implies that $\alpha_{1}^{(.)}<0$.

The test for conditional convergence is specified as follows:

$$
D_{i j, t}{ }^{d}=\ln \left(\left(X_{i j, t}-\bar{X}_{i j}\right) / \bar{X}_{i j}\right)=\gamma_{0}{ }^{d}+\gamma_{1}^{d} \ln \left(\bar{X}_{i j}\right)+\gamma_{2}^{d} Z+\varepsilon_{i t}{ }^{d}
$$

Nested OLS regressions are estimated to quantify the additional information added to the estimates of $D_{i j, t}$ by introducing the conditioning variables $(Z)$. Conditional sigma convergence implies that $\gamma_{1}{ }^{d}<0$. Z is a vector of conditioning characteristics in the Mercosur, which hold the benchmark constant for each bank $j$. Because of the preference of $\sigma$ over $\beta$ in measuring convergence, we focus on conditional $\sigma$-convergence. This is because $\beta$-convergence can still be observed as a result of measurement error and random shocks. Therefore, if $\beta$-convergence is to measure real convergence it must coincide with $\sigma$-convergence. 
8. There are three sets of conditioning variables used. The first set controls for differences in bank characteristics that may condition convergence in bank behavior. They are size (measured by the logarithm of total assets); profitability (measured by return on assets); and capitalization (measured as the ratio of equity to total assets).

9. The second group of control variables reflects the overall institutional quality in the country. We use the Kaufman, Kraay and Mastruzzi (2008) governance indicators to build a composite index of six dimensions of governance based on the following subgroupings: voice and accountability, political stability, government effectiveness, regulatory quality, the rule of law, and the control of corruption. This broad measure has been widely used in empirical studies such as (Dimirgüç-Kunt et al. 2006b).

10. The third set of controls reflects the macroeconomic environment. We use real GDP growth, inflation, and the percentage of total reserves to external debt (as an indicator of the strength of the external balance).

\section{We also use two external benchmarks to assess the robustness of our results} since the validity of our results is based on the quality of the internal benchmark as a measure of normal bank behavior. These are Norway (an OECD country) and Chile (a regional benchmark). Using a regional benchmark incorporates controls for specific regional peculiarities in the banking system that may cause banks in Latin America, for example, to behave differently from other banking system in the world. ${ }^{4}$ Implicit in this is the fact that bank fundamentals in the Mercosur do not necessarily need to move in line with the rest of the world to be considered normal.

\section{Data Sources and Issues}

12. For the identification and timing of systemic banking crises, we rely on a widely used database by Caprio and Klingebiel (2003). Accordingly, a systemic crisis episode is characterized by large-scale bank failures, the adoption of emergency measures by the government, significant bank runs, high levels of non-performing loans and significant bailout costs.

\footnotetext{
${ }^{4}$ The test for absolute and conditional $\sigma$-convergence to external benchmarks is conducted by estimating equation (5) and (6) with the following modification to the measures of dispersion:

$Y_{i, t}=\ln \left(X_{i, t} / X_{i, t}\right)$

For all $i=\{$ Argentina, Brazil, Paraguay,Uruguay $\}, i^{\prime}=\{$ Chile, Norway $\}$ and across all $t^{\prime} s$.

$X_{i, t}=\sum_{j=1}^{J} X_{i j, t} / J, X_{i, t}=\sum_{j=1}^{J} X_{i j, t} / J \mathrm{j}=1,2 \ldots \mathrm{J}$ (averaging is across banks)

$D_{i, t}=$ The cross sectional standard deviation between $i$ and $i^{\prime}$.
} 


\section{We use a panel of banks, using bank-level data from the Bankscope database}

(Table 3). There are 115 existing banks in the baseline sample. Macroeconomic variables are from the IMF (International Financial Statistics, IFS) and the World Bank (World Development Indicators, WDI) databases. ${ }^{5}$ The following systemic crisis episode occurring within the period is considered: Argentina (1995), Brazil (1994), Paraguay (1995), and Uruguay (2002).

Table 3. Mercosur: Summary of Coverage of Crises and Banks

\begin{tabular}{lcccr}
\hline & $\begin{array}{c}\text { Systemic Crises } \\
\text { Argentina }\end{array}$ & $\begin{array}{c}\text { No. of Banks } \\
\text { in sample }\end{array}$ & $\begin{array}{c}\text { No.of Banks in the Banking } \\
\text { System (Bankscope) 2005 }\end{array}$ & Fraction of Total Assets \\
\hline Brazil & $1995,(2001)$ & 62 & 111 & 65 \\
Paraguay & $1994-1999$ & 20 & 201 & 56 \\
Uruguay & $1995-1999$ & 13 & 26 & 66 \\
Total & 2002 & 20 & 49 & \\
\hline
\end{tabular}

Sources: Bankscope and authors' calculations.

Observations are measured in yearly intervals from the onset of the systemic crisis.

\section{The Results}

\section{Descriptive Statistics}

\section{A number of stylized facts emerge from a quick overview of the descriptive} statistics (Table 4). First, within the sample period, the average level of profitability (ROA) is negative. Second, banks in the Mercosur on average held a higher level of liquid assets (36 percent) of total assets compared to banks in Chile (with a much lower average of 9 percent). Third, regarding the pattern of intermediation, the Mercosur countries compared to the external benchmarks are more heavily involved in government financing. Private and public sector credit by commercial banks is 26 and 12 percent of GDP, respectively, in the Mercosur compared to Chile where the levels are 90 and 1 percent of GDP. In Norway, the commercial banks credit to the private sector is 67 percent of GDP and 7 percent to the public sector.

\section{Regression Analysis}

\section{Overall results}

\section{Table 5 shows estimates of equations 4-6 using nested OLS regressions. We} report the regression coefficients $\alpha_{1}^{y}, \alpha_{1}^{d}$ and $\gamma_{1}^{d}$ and their associated standard errors. We also report the incremental $R^{2}$ (through nested regressions) to reflect the additional information (if any) that holding a specific group of control variables constant adds to the rate of convergence. To aid interpretation, we explain the results in light of the extent to which the benchmark is an appropriate measure of normal bank behavior. We focus our attention on $\sigma$ -

\footnotetext{
${ }^{5}$ A fuller description of data sources and definitions is given in Appendix I.
} 
convergence measures, even though we report both in our canonical model. This is because the measure of $\beta$-convergence must coincide with $\sigma$-convergence for real convergence to occur. $^{6}$

\section{The most notable result is the lack of convergence in two measures of} intermediation (credit by banks/GDP and private credit/GDP). The estimates of $\alpha_{1}^{d}$ and $\gamma_{1}^{d}$ are positive and significant, which implies that the total credit supplied by banks as well as the proportion of credit to the private sector, have yet to recover to the precrisis level. This result remains robust to the

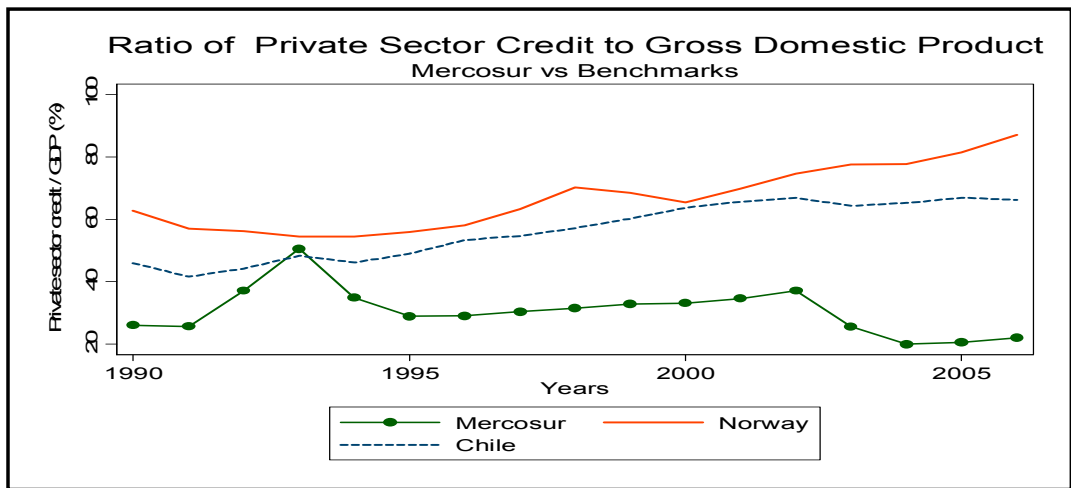
inclusion of control factors. In other words, holding constant the possible effects that macroeconomic conditions, institutional adequacy, as well as bank specific characteristics may have on the recovery of private sector intermediation does not change the results. That said, if banking crisis is preceded by an unsustainable growth in credit, we might not find convergence to the pre-crisis levels of credit supply. Hence we do not identify problematic bank behavior solely based on non-convergence in levels of intermediation without looking at changes to the pattern of intermediation.

17. We find a high rate of convergence (-0.72) in public credit. This indicates that precrisis levels of government financing will typically be exceeded within two years after crisis. This increased public sector financing may explain the declining levels of credit to the private sector.

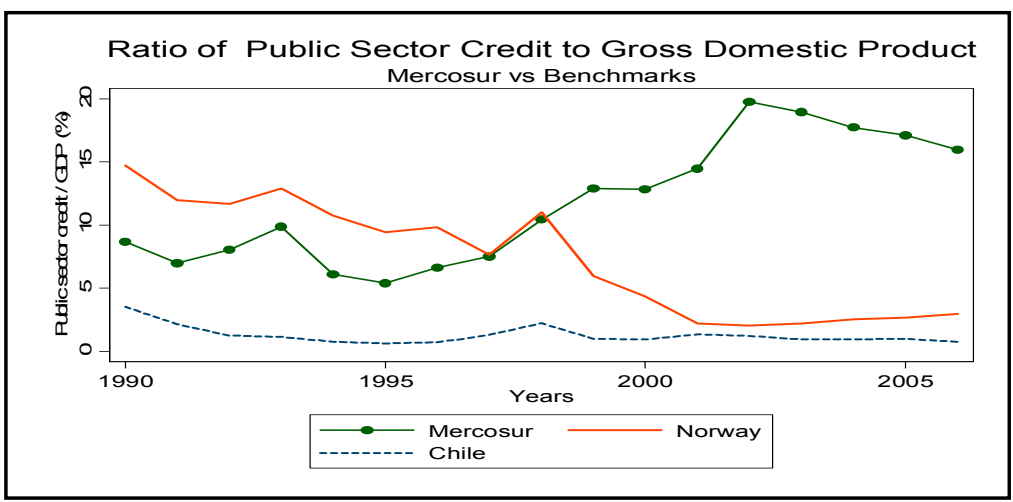

\footnotetext{
${ }^{6}$ There are instances where the coefficients of $\beta$ - and $\sigma$-convergence yield very different estimates, particularly for variables where convergence is "bottom up"-in which case absolute values of $Y_{i j, t}$ will increase for convergence to occur, while absolute values of $D_{i j, t}$ will decrease to show convergence. This further highlights the bias that can be caused by relying on the $\beta$ instead of $\sigma$ to show convergence.
} 
Table 4. Mercosur: Bank Behavior Summary Statistics

\begin{tabular}{|c|c|c|c|c|c|c|}
\hline Variable & & Mean & Median & SD & Min & Max \\
\hline \multicolumn{7}{|l|}{ Profitability } \\
\hline \multirow[t]{5}{*}{ Return on Assets (ROA) } & Aggregate & -0.46 & 0.79 & 8.14 & -135.07 & 22.06 \\
\hline & Argentina & -1.54 & 0.37 & 8.62 & -94.58 & 22.60 \\
\hline & Brazil & 1.67 & 1.44 & 3.15 & -9.25 & 18.75 \\
\hline & Paraguay & 1.79 & 2.19 & 3.31 & -23.72 & 11.21 \\
\hline & Uruguay & -1.63 & 0.06 & 13.05 & -135.07 & 6.20 \\
\hline \multirow[t]{5}{*}{ Net Interest Margin } & Aggregate & 7.39 & 6.02 & 8.62 & -38.74 & 101.45 \\
\hline & Argentina & 5.45 & 4.62 & 6.86 & -36.73 & 82.54 \\
\hline & Brazil & 12.24 & 8.90 & 13.46 & -2.74 & 101.45 \\
\hline & Paraguay & 10.38 & 10.49 & 3.11 & 4.53 & 19.34 \\
\hline & Uruguay & 4.94 & 5.01 & 5.72 & -38.74 & 18.94 \\
\hline \multicolumn{7}{|l|}{ Risk } \\
\hline \multirow[t]{5}{*}{ Ratio of Equity to Asset } & Aggregate & 15.96 & 11.61 & 18.82 & -172.88 & 99.05 \\
\hline & Argentina & 18.65 & 12.45 & 20.18 & -110.35 & 99.05 \\
\hline & Brazil & 14.14 & 9.91 & 14.27 & -45.56 & 99.04 \\
\hline & Paraguay & 14.24 & 13.17 & 4.51 & 4.70 & 27.92 \\
\hline & Uruguay & 8.86 & 7.85 & 18.66 & -172.88 & 81.87 \\
\hline Spread (Lending- Deposit) & Aggregate & 16.04 & 10.46 & 15.75 & 1.98 & 58.36 \\
\hline \multicolumn{7}{|l|}{ Credit Supply } \\
\hline \multirow[t]{5}{*}{ Bank Loans/Asset Ratio } & Aggregate & 47.50 & 47.73 & 20.21 & -10.18 & 99.72 \\
\hline & Argentina & 44.14 & 45.69 & 18.82 & -10.18 & 86.88 \\
\hline & Brazil & 38.22 & 36.83 & 13.88 & -0.01 & 89.53 \\
\hline & Paraguay & 49.26 & 53.12 & 14.43 & 5.47 & 83.54 \\
\hline & Uruguay & 73.91 & 78.15 & 17.55 & 16.98 & 99.72 \\
\hline Domestic Money Bank Credit to the Private Sector/GDP & Aggregate & 0.26 & 0.22 & 0.17 & 0.10 & 1.33 \\
\hline Domestic Money Banks Total Credit to the Public sector/GDP & Aggregate & 0.12 & 0.09 & 0.11 & 0.00 & 0.42 \\
\hline Total Credit by Deposit Money Banks/GDP & Aggregate & 43.91 & 33.99 & 24.94 & 14.92 & 181.46 \\
\hline \multicolumn{7}{|l|}{ Maturity Preference } \\
\hline \multirow[t]{5}{*}{ Banks Total Deposits/Assets ratio } & Aggregate & 0.63 & 0.68 & 0.24 & 0.00 & 3.04 \\
\hline & Argentina & 0.61 & 0.67 & 0.24 & 0.00 & 3.04 \\
\hline & Brazil & 0.38 & 0.38 & 0.18 & 0.01 & 1.09 \\
\hline & Paraguay & 0.70 & 0.72 & 0.11 & 0.87 & 0.27 \\
\hline & Uruguay & 0.89 & 0.89 & 0.27 & 0.18 & 2.54 \\
\hline Liquid Liabilities (Demand Deposits/Total Deposits and Short term & Aggregate & 0.22 & 0.11 & 0.27 & 0.00 & 1.53 \\
\hline \multirow[t]{4}{*}{ Funding) } & Argentina & 0.16 & 0.10 & 0.20 & 0.00 & 1.53 \\
\hline & Brazil & 0.09 & 0.08 & 0.08 & 0.00 & 0.47 \\
\hline & Paraguay & 0.64 & 0.80 & 0.33 & 0.00 & 1.00 \\
\hline & Uruguay & 0.57 & 0.92 & 0.42 & 0.03 & 0.95 \\
\hline \multirow[t]{5}{*}{ Liquid Assets (Liquid Assets/Total Assets) } & Aggregate & 0.36 & 0.34 & 0.19 & 0.00 & 1.18 \\
\hline & Argentina & 0.38 & 0.34 & 0.20 & 0.03 & 1.18 \\
\hline & Brazil & 0.42 & 0.42 & 0.14 & 0.00 & 0.73 \\
\hline & Paraguay & 0.37 & 0.34 & 0.14 & 0.10 & 0.88 \\
\hline & Uruguay & 0.19 & 0.14 & 0.16 & 0.00 & 0.77 \\
\hline
\end{tabular}

Sources: Bankscope, WDI, IFS and authors' calculations. 
Table 5. Mercosur: Summary Results for Absolute and Conditional Convergence 1/

\begin{tabular}{|c|c|c|c|c|c|}
\hline & \multirow[b]{3}{*}{$\beta$-conv } & \multirow[t]{3}{*}{ Convergence } & \multicolumn{3}{|c|}{ Conditional Convergence } \\
\hline & & & $\begin{array}{l}\text { Bank level } \\
\text { controls }\end{array}$ & $\begin{array}{l}\text { Macroeconomic } \\
\text { Controls }\end{array}$ & $\begin{array}{l}\text { Institutional \& } \\
\text { Markert Structure } \\
\text { Controls }\end{array}$ \\
\hline & & & & $\sigma$ - conv & \\
\hline & 1 & 2 & 3 & 4 & 5 \\
\hline \multicolumn{6}{|l|}{ Profitability } \\
\hline \multirow[t]{3}{*}{ Return on Assets } & $-0.668^{* \star *}$ & $-0.602^{\star \star *}$ & $-0.706^{\star * *}$ & $-0.606^{\star * *}$ & $-0.662^{* * *}$ \\
\hline & 0.059 & 0.065 & 0.064 & 0.065 & 0.068 \\
\hline & & & $0.22^{* \star *}$ & $0.04^{\star \star *}$ & $0.03^{* * *}$ \\
\hline \multicolumn{6}{|l|}{ Risk } \\
\hline \multirow[t]{3}{*}{ Capitalization } & $-0.417^{\star * *}$ & $-0.360^{* * *}$ & $-0.452^{* * *}$ & $-0.383^{\star * *}$ & $-0.313^{* * *}$ \\
\hline & 0.055 & 0.09 & 0.107 & 0.086 & 0.099 \\
\hline & & & $0.05^{\star * *}$ & $0.03^{* * *}$ & $0.02^{\star \star *}$ \\
\hline \multicolumn{2}{|c|}{ Spread (Lending -Deposit Interest $-0.326^{\star \star *}$} & $-0.238^{* * *}$ & $-0.193^{* * *}$ & $-0.076^{* * *}$ & $0.367^{\star \star \star}$ \\
\hline \multirow[t]{2}{*}{ Rate) } & 0.024 & 0.039 & 0.049 & 0.052 & 0.073 \\
\hline & & & $0.05^{\star}$ & $0.31^{* * *}$ & $0.41^{* * *}$ \\
\hline \multicolumn{6}{|l|}{ Credit Supply } \\
\hline \multirow[t]{3}{*}{ Loans/Assets } & $-0.418^{* * *}$ & $-0.347^{\star * *}$ & $-0.448^{* * *}$ & $-0.378^{* * *}$ & $0.345^{\star * *}$ \\
\hline & 0.083 & 0.104 & 0.119 & 0.106 & 0.118 \\
\hline & & & 0.00 & $0.02^{\star * *}$ & $0.06^{\star * *}$ \\
\hline \multirow[t]{3}{*}{ Credit by banks/GDP } & $-0.547^{* * *}$ & $0.106^{\star * *}$ & 0.016 & $0.304^{\star * *}$ & $0.761^{* * *}$ \\
\hline & 0.01 & 0.021 & 0.039 & 0.029 & 0.051 \\
\hline & & & $0.12^{* * *}$ & $0.21^{* \star *}$ & $0.28^{* * *}$ \\
\hline \multirow[t]{3}{*}{ Private Credit/ GDP } & $-0.525^{\star \star \star}$ & $0.549^{* * *}$ & $0.349^{\star \star \star}$ & $0.765^{\star \star \star}$ & $0.764^{\star \star \star}$ \\
\hline & 0.013 & 0.018 & 0.038 & 0.029 & 0.085 \\
\hline & & & $0.08^{* * *}$ & $0.20^{\star * *}$ & $0.45^{\star \star *}$ \\
\hline \multirow[t]{3}{*}{ Public Credit/GDP } & $-0.582^{\star * *}$ & $-0.723^{\star \star *}$ & $-0.780^{* * *}$ & $-0.791^{\star \star *}$ & $-0.498^{\star \star *}$ \\
\hline & 0.006 & 0.003 & 0.011 & 0.013 & 0.013 \\
\hline & & & $0.02^{* * *}$ & $0.02^{* * *}$ & $0.15^{\star \star \star}$ \\
\hline \multicolumn{6}{|l|}{ Liquidity } \\
\hline \multirow[t]{3}{*}{ Total Deposits/Assets } & $-0.905^{\star * *}$ & $0.424^{\star * *}$ & $0.424^{* * *}$ & $0.396^{* * *}$ & $0.341^{* \star *}$ \\
\hline & 0.04 & 0.047 & 0.035 & 0.04 & 0.035 \\
\hline & & & $0.06^{* * *}$ & $0.09^{* * *}$ & $0.007^{\star \star *}$ \\
\hline \multirow[t]{3}{*}{ Demand deposits/Total Deposits } & $-0.360^{\star * *}$ & $-0.216^{\star *}$ & $-0.290^{* * *}$ & $-0.258^{\star * \star *}$ & $-0.375^{\star \star \star}$ \\
\hline & 0.078 & 0.092 & 0.085 & 0.083 & 0.088 \\
\hline & & & $0.02^{\star \star \star}$ & $0.06^{\star \star *}$ & $0.26^{* \star *}$ \\
\hline \multirow[t]{3}{*}{ Liquid Assets/Total Assets } & $-0.723^{\star * *}$ & $-0.769^{* * *}$ & $-0.729^{\star *}$ & $-0.704^{* * *}$ & $-0.680^{\star * *}$ \\
\hline & 0.031 & 0.11 & 0.113 & 0.109 & 0.117 \\
\hline & & & 0.00 & $0.05^{\star \star *}$ & $0.03^{* * *}$ \\
\hline \multirow[t]{3}{*}{ Res/GDP } & $-0.230^{* * *}$ & $-0.912^{\star * *}$ & $-1.004^{\star * *}$ & $-0.558^{\star * *}$ & $-0.989^{\star * *}$ \\
\hline & 0.024 & 0.034 & 0.042 & 0.036 & 0.045 \\
\hline & & & $0.14^{* * *}$ & $0.19^{* * *}$ & $0.23^{* * *}$ \\
\hline
\end{tabular}

Source: Authors' calculations.

$1 /$ The first row is the parameter estimate, the second row is the standard error, and the final row shows the incremental R2. Nested OLS regressions including all banks. Robust standard errors are reported in parentheses. ${ }^{* * *},{ }^{* *}$, and ${ }^{*}$ indicate statistical significance at the 1,5 and 10 percent levels, respectively. 
18. Although we also find evidence of convergence in the loans/asset ratio, we are cautious in interpreting this as a rise in private sector credit for two reasons. First, because the variable does not distinguish between loans recipients (private or public sector) it is likely that the coefficient is simply capturing the effects of increased public sector financing. Second, since the condition imposed in the data collection process is for banks to be in existence before and after crisis, bank level data may indicate survivorship bias, as only the largest and most profitable intermediaries will have survived systemic banking. Another possible explanation for the lack of convergence in levels of intermediation may be because other bank fundamentals have not recovered to their pre-crisis levels and hence cannot sustain higher levels of intermediation in the Mercosur. We thus examine whether or not there is convergence in levels of profitability, risk, as well as the maturity composition and funding structure of the banks portfolio.

\section{There is a high and significant rate of convergence (-0.60) in bank profitability}

$(\boldsymbol{R} \boldsymbol{O} \boldsymbol{A})$. This shows that banks quickly recover pre-crisis levels of profitability (within 2 years). This is intuitive considering that only the most resilient banks will survive a banking crisis. It is therefore difficult to ascribe lower levels of intermediation to lack of profitability in banks.

20. We also find convergence in capitalization and spreads to be significant. While intermediation spreads within the region are still relatively high, they are nonetheless trending downwards. For example, in Brazil spreads have declined by about 17 percentage points between 1997 and 2006 and in Uruguay by about 30 percent within the same period. We also find that the estimates of $\alpha_{1}^{d}$ and $\gamma_{1}^{d}$ for capitalization and spreads are robust to the inclusion of control factors. Holding the effect of the macroeconomy constant in the Mercosur significantly reduces the speed of convergence from about 24 percent $(-0.238)$ to 8 percent (-0.076) per year, evidence of a significant influence of macroeconomic conditions on the pricing of risk in banks within the Mercosur.

\section{In summary, we find evidence of persistent decline in private sector credit after} systemic banking crises in the Mercosur. This happens even though the levels of other bank fundamentals have converged back to the pre-crisis levels and are such that can support increased levels of intermediation. We also find that post-crisis recovery of banks is largely predicated on holding highly levels of liquidity and lending to the public sector, typically in the form of purchasing highly liquid government securities and holding excess reserves, which is also a sub-optimal pattern of intermediation. Our results also hold in the presence of controls for other bank characteristics, the condition of the macroeconomy, and importantly the level of institutional development as well as the structure of the banking system. 


\section{Results by country}

22. We estimate equations $\mathbf{4}$ and $\mathbf{5}$ for individual countries only using bank-level data and present estimates of $\alpha_{1}^{d}$ and $\gamma_{1}^{d}$ in Table $6 .{ }^{7}$ We also introduce the ratio of loan loss provisioning to net interest revenue to capture another element of bank risk, which may further explain lower levels of intermediation.

- $\quad$ Argentina. We do not find evidence of post-crisis recovery in measures of intermediation (loans and loans/asset ratios) even when the other conditioning factors are held constant. As in the analysis of the full sample, we cannot attribute these lower levels of intermediation to lack of profitability in banks. However, the fact that we also find a very high rate of convergence in loan loss provisioning, liquid asset holdings and a continued loss of preference for deposits in domestic currency may explain the persistent decline in levels of intermediation.

- Brazil. We find that the high level of convergence in the measure of intermediation (loans/assets) is highly conditioned by the overall institutional adequacy and banking system structure. This highlights the effective role played by the stabilization measures implemented to strengthen the financial system after crisis on the recovery of bank credit.

Contrary to the full sample result, we do not find convergence in holding of liquid assets and levels of capitalization. The lack of recovery of deposits more or less reflects the shrinking of the institutions surveyed as opposed to a continued run on deposits since aggregate levels of deposits remain stable.

- $\quad$ Paraguay. In line with the full sample, we find high rates of convergence in liquid asset holdings, and loan loss provisioning. However, there is no convergence in the measure of intermediation (ratio of loan to assets) and in the level of deposits especially longer-term deposits. It also appears that systemic crises and subsequent bouts of banking distress in the region have eroded the level of capitalization of banks, which may have contributed to the shrinking loan portfolio in banks. Another possible reason for the reduced intermediation is the relative lack term deposits as a result of a shift in preferences by depositors towards sight deposits. This in turn reflects continued reduced confidence in the banking system.

- Uruguay. Unlike for the other countries, we find rapid recovery in levels of intermediation (loans/assets ratio). Other measures of bank fundamentals such as

\footnotetext{
${ }^{7}$ Estimating aggregate data is impossible in the panel of banks by country and the measures will not vary across panels.
} 
loan loss provisioning/net interest revenue, capitalization, and liquid assets/total assets ratios also show rapid rates of convergence. We do not find convergence in levels of deposits and intermediation spreads. Since the crisis in Uruguay is comparatively more recent than in the other Mercosur countries, it is possible that post crisis-recovery is still ongoing and results may be significantly different in a couple of years.

Table 6. Mercosur: Results for Absolute and Conditional Sigma Convergence by Country $1 /$

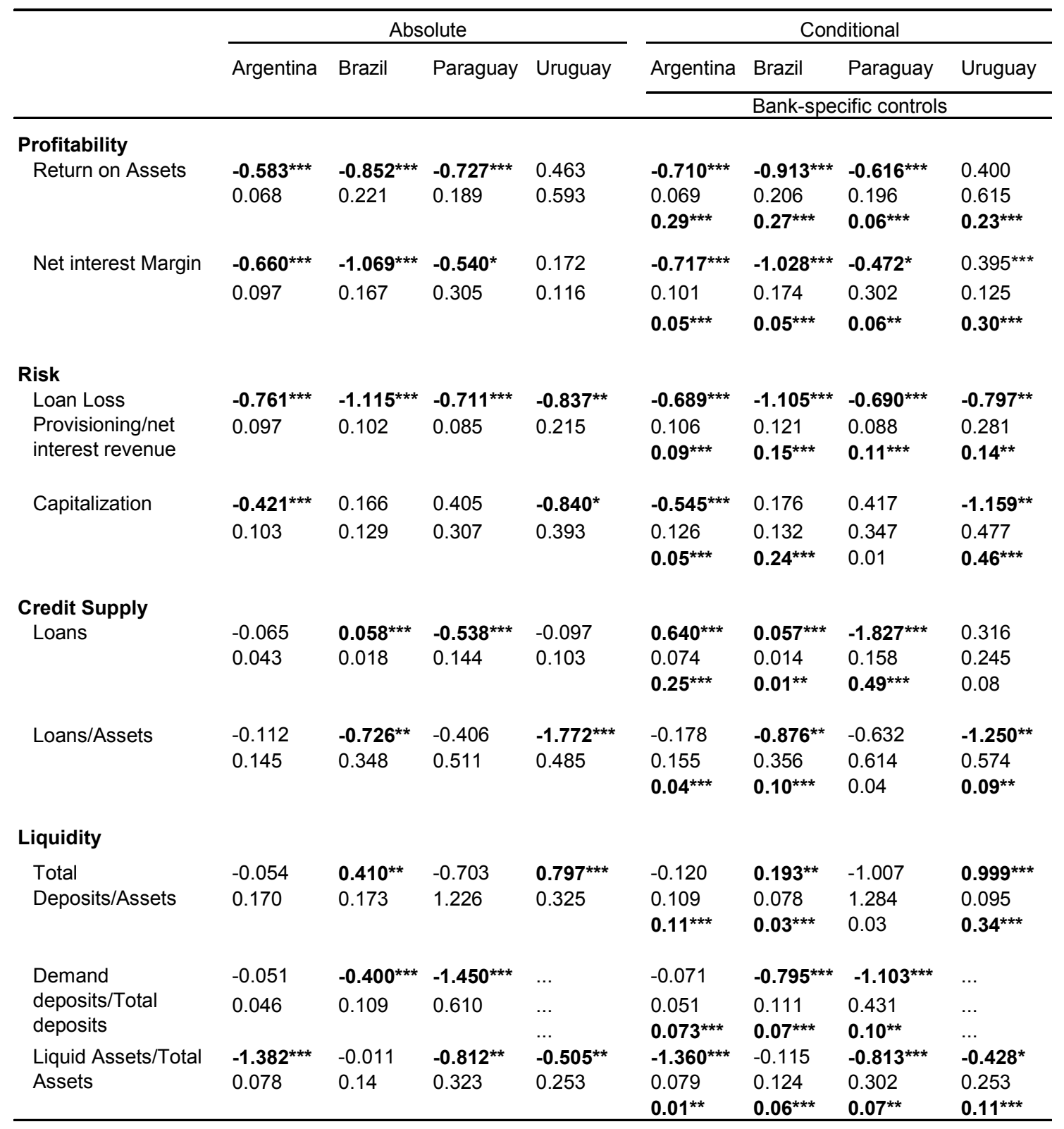

Source: Authors' calculations.

$1 /$ The first row is the parameter estimate, the second row is the standard error, and the final row shows the incremental R2. Nested OLS regressions including all banks. Robust standard errors are reported in parentheses. ${ }^{* * *},{ }^{* *}$, and ${ }^{*}$ indicate statistical significance at the 1,5 and 10 percent levels, respectively. 
23. In summary, there are considerable variations in results in individual countries compared to the overall sample. This is particularly the case with respect to the role played by the conditioning variables on the rates of convergence. However, some trends remain common. The first is the high liquidity characteristic of the balance sheet (liquid assets and loan loss provisioning), which may be sub-optimal for lending. While the observed bank behavior regarding intermediation and liquidity may indeed be related to past experiences with instability in the region, it becomes a deterrent to private sector intermediation if it nurtures risk aversion. Unfortunately, the lack of convergence in private sector intermediation reported in the overall results may persist since banks in the Mercosur have maintained profitability independent of private sector intermediation.

\section{Alternative benchmarks}

\section{In this sub-section we focus on analyzing changes in bank behavior over the}

entire period. To do this, we choose an external time-varying benchmark, which also has the following added advantages. First, the use of pre-crisis average of bank fundamentals itself may be a flawed benchmark for normal bank behavior because levels of credit supply may be at an unsustainable high before the crisis and hence banks may now be at an equilibrium point that is different from their pre-crisis levels. Structural changes, regulatory and macroeconomic developments are other factors that can also pre-empt the lack of internal convergence.

\section{Second, the use of an external benchmark enhances the meaning and}

comparability of the rates of convergence. The use of a pre-crisis average as a benchmark for normal bank behavior means that each bank is converging to a different benchmark even though the method of constructing the benchmark remains the same. In other words, the fact that there are different rates of convergence to different benchmarks may sometimes impair the interpretation of convergence. The use of alternative benchmarks mitigates this problem as convergence is not to an internal benchmark which would be unique for each bank, but to a single external benchmark.

\section{The choice of external}

benchmark is Chile (regional comparator) and Norway (OECD benchmark). Chile's last systemic banking crisis was in 1981-86 and Norway in 1987-93. The Norwegian banking crisis also has similar elements to crises in some of the countries in the Mercosur - a rapid economic boom and deregulation during 1984-87. However, sound macroeconomic conditions and

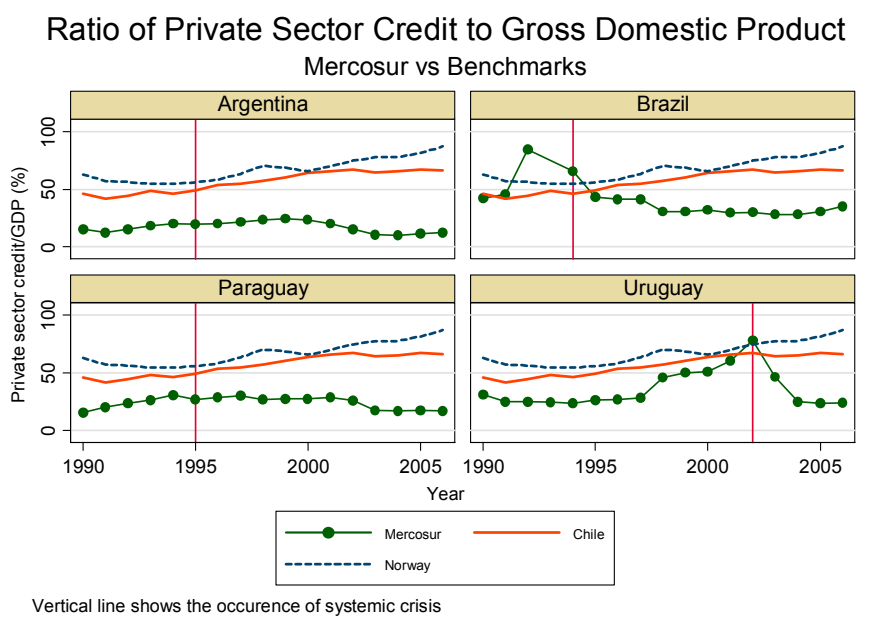


well functioning institutions made for much quicker and effectively aided post-crisis stabilization.

\section{The results also show a lack of significant convergence in the amount of credit supplied particularly to the private sector to both external benchmarks (Table 7). A} more notable peculiarity is the fact that the coefficient of private sector credit is positive and significant (divergence). This means private sector credit has grown at a faster rate in Chile and Norway than in the Mercosur. There is also a steady growth in the ratio of loans to assets and private sector credit in the benchmarks as opposed to the decline observed in the Mercosur.

Table 7. Mercosur: Summary Results for Sigma Convergence Using Chile and Norway as Alternative Benchmarks

\begin{tabular}{|c|c|c|c|c|c|c|}
\hline & \multicolumn{2}{|c|}{ Absolute } & \multicolumn{4}{|c|}{ Conditional } \\
\hline & \multirow[b]{2}{*}{ Chile } & \multirow[b]{2}{*}{ Norway } & \multicolumn{2}{|c|}{ Macroeconomy } & \multicolumn{2}{|c|}{ Institutions } \\
\hline & & & Chile & Norway & Chile & Norway \\
\hline \multicolumn{7}{|l|}{ Profitability } \\
\hline Return on Assets & $\begin{array}{l}-0.476^{* *} \\
0.197\end{array}$ & $\begin{array}{l}-0.093 \\
0.230\end{array}$ & $\begin{array}{l}-\mathbf{0 . 4 0 9 *} \\
0.205 \\
0.040\end{array}$ & $\begin{array}{l}-0.353 \\
0.231 \\
0.17^{\star \star \star}\end{array}$ & $\begin{array}{l}-0.516 \\
0.986 \\
0.21^{*}\end{array}$ & $\begin{array}{l}-0.152 \\
0.309 \\
0.23^{\star \star}\end{array}$ \\
\hline \multicolumn{7}{|l|}{ Risk } \\
\hline Capitalization & $\begin{array}{l}-0.992^{\star * *} \\
0.284\end{array}$ & $\begin{array}{l}0.287 \\
0.687\end{array}$ & $\begin{array}{l}-1.147^{\star * *} \\
0.271 \\
0.14^{\star \star *}\end{array}$ & $\begin{array}{l}3.090^{\star \star *} \\
0.832 \\
0.13^{\star \star \star}\end{array}$ & $\begin{array}{l}-1.590^{\star *} \\
0.705 \\
0.17^{\star *}\end{array}$ & $\begin{array}{l}1.720^{* * *} \\
0.934 \\
0.190\end{array}$ \\
\hline Spread (Lending -Deposit Interest Rate) & $\begin{array}{l}-0.401 \\
0.732\end{array}$ & $\begin{array}{l}-0.150 \\
0.739\end{array}$ & $\begin{array}{l}-1.476^{*} \\
0.792 \\
0.14^{\star \star}\end{array}$ & $\begin{array}{l}-\mathbf{3 . 4 5 7} 7^{\star \star *} \\
1.041 \\
0.21^{\star * *}\end{array}$ & $\begin{array}{l}0.402 \\
0.757 \\
0.33^{\star * \star}\end{array}$ & $\begin{array}{l}2.64 \\
3.871 \\
0.37^{\star * *}\end{array}$ \\
\hline \multicolumn{7}{|l|}{ Credit Supply } \\
\hline Loans/Assets & $\begin{array}{l}3.042^{* *} \\
1.515\end{array}$ & $\begin{array}{l}0.310 \\
1.000\end{array}$ & $\begin{array}{l}3.193^{\star \star \star} \\
1.652 \\
0.09^{\star \star \star}\end{array}$ & $\begin{array}{l}-0.666 \\
0.930 \\
0.040\end{array}$ & $\begin{array}{l}1.286 \\
1.920 \\
0.200\end{array}$ & $\begin{array}{l}3.919 \\
2.716 \\
0.35^{\star \star *}\end{array}$ \\
\hline Credit by Banks/GDP & $\begin{array}{l}0.441 \\
0.535\end{array}$ & $\begin{array}{l}-1.570 \\
1.886\end{array}$ & $\begin{array}{l}0.478 \\
0.665 \\
0.130\end{array}$ & $\begin{array}{l}1.745 \\
1.253 \\
0.26^{\star \star}\end{array}$ & $\begin{array}{l}-0.566 \\
0.921 \\
0.47^{\star \star \star}\end{array}$ & $\begin{array}{l}2.874^{\star} \\
1.435 \\
0.39^{\star \star \star}\end{array}$ \\
\hline $\begin{array}{l}\text { Deposit Money Banks Private } \\
\text { Credit/GDP }\end{array}$ & $\begin{array}{l}1.544^{* * *} \\
0.473\end{array}$ & $\begin{array}{l}1.544^{\star * *} \\
0.373\end{array}$ & $\begin{array}{l}1.752^{\star \star \star} \\
0.478 \\
0.13^{\star \star \star}\end{array}$ & $\begin{array}{l}1.601^{\star \star *} \\
0.255 \\
0.17^{\star \star}\end{array}$ & $\begin{array}{l}2.673^{\star} \\
1.436 \\
0.14^{\star \star}\end{array}$ & $\begin{array}{l}1.594 \\
1.090 \\
0.15^{*}\end{array}$ \\
\hline $\begin{array}{l}\text { Deposit Money banks } \\
\text { Public credit/GDP }\end{array}$ & $\begin{array}{l}0.158 \\
0.328\end{array}$ & $\begin{array}{l}0.089 \\
0.275\end{array}$ & $\begin{array}{l}-0.460 \\
0.327 \\
0.33^{\star * *}\end{array}$ & $\begin{array}{l}0.183 \\
0.301 \\
0.030\end{array}$ & $\begin{array}{l}1.078 \\
0.682 \\
0.51^{* * *}\end{array}$ & $\begin{array}{l}0.009 \\
0.552 \\
0.29^{*}\end{array}$ \\
\hline $\begin{array}{l}\text { Liquidity } \\
\text { Res GDp }\end{array}$ & $\begin{array}{l}-0.349 \\
0.567\end{array}$ & $\begin{array}{l}-0.455^{\star *} \\
0.200\end{array}$ & $\begin{array}{l}-0.448 \\
0.567 \\
0.060\end{array}$ & $\begin{array}{l}-0.206 \\
0.220 \\
0.11^{*}\end{array}$ & $\begin{array}{l}0.198 \\
0.681 \\
0.100\end{array}$ & $\begin{array}{l}-0.574 \\
0.544 \\
0.120\end{array}$ \\
\hline Demand deposit/GDP & $\begin{array}{l}0.225 \\
0.845\end{array}$ & $\begin{array}{l}0.991^{* * *} \\
0.039\end{array}$ & $\begin{array}{l}-1.299 \\
0.818 \\
0.32^{\star *}\end{array}$ & $\begin{array}{l}0.957^{* * *} \\
0.038 \\
0.01^{*}\end{array}$ & $\begin{array}{l}0.919 \\
1.104 \\
0.29^{\star \star}\end{array}$ & $\begin{array}{l}1.012^{\star \star \star} \\
0.044 \\
0.04^{\star \star \star}\end{array}$ \\
\hline \multirow[t]{2}{*}{ Liquid Assets/Total Assets } & $\begin{array}{l}-0.686^{*} \\
0.380\end{array}$ & $\begin{array}{l}0.560 \\
0.520\end{array}$ & $\begin{array}{l}-0.630 \\
0.380\end{array}$ & $\begin{array}{l}-0.564 \\
0.566\end{array}$ & $\begin{array}{l}-\mathbf{0 . 6 0 6} \\
0.212\end{array}$ & $\begin{array}{l}-1.865^{\star *} \\
0.848\end{array}$ \\
\hline & & & 0.020 & 0.020 & 0.110 & $0.11^{\star *}$ \\
\hline
\end{tabular}

Source: Authors' calculations.

$1 /$ The first row is the parameter estimate, the second row is the standard error, and the final row shows the incremental R2. Nested OLS regressions including all banks. Robust standard errors are reported in parentheses.

${ }^{* * *},{ }^{* *}$, and ${ }^{*}$ indicate statistical significance at the 1,5 and 10 percent levels, respectively. 
28. We find that macroeconomic conditions in the Mercosur are the main reason behind the lack of significant convergence in spreads to any of the external benchmarks. Furthermore, intermediation spreads are also higher in the Mercosur than the benchmark countries. This reflects the relatively higher levels of interest rates in the region, as banks typically set higher interest rates in response to their risk exposure. In addition, we find that the level of liquidity (liquid assets and reserves) is consistently higher in the Mercosur particularly after crisis. However, we find that the results are reversed when we hold constant the impact of institutional quality in the Mercosur.

29. Our results show that the behavior of banks in the Mercosur within the sample period is generally not inline with external benchmarks. The only exception is for profitability and capitalization. The convergence to the regional benchmark in terms of profitability and capitalization is not surprising as profitability may be necessary for the continued existence of the banks, and levels of capitalization may be driven by regulatory requirements. The wide disparity that we observe between the Mercosur and the benchmark seems to have been present before systemic crisis. However, it shows levels of private sector intermediation that are persistently low with little sign of recovery.

\section{E. Concluding Remarks}

30. The paper has explored the post-banking crisis behavior of banks in the Mercosur, with particular emphasis on fundamental and undesirable changes. It has explored the behavior of banks before and after the occurrence of a systemic crisis using convergence analysis, focusing on volume and nature of intermediation. The paper characterizes as sub-optimal a behavior whereby there is lack of convergence to both the precrisis average and to an external benchmark. This two-way analysis is important because categorization by only using other countries banking systems as external benchmarks can be misleading. To the extent that the pre-crisis levels of bank behavior is a peculiarity of the Mercosur countries and not a standard for normal bank behavior, banks in the Mercosur would be different from external benchmarks.

\section{The main finding of the paper is a persistent decline in private sector} intermediation that is out of line with internal and external benchmarks. This can be attributed to the role played by macroeconomic and institutional volatility that has nurtured a relatively high level of risk aversion by banks in the Mercosur, as well as a lower level of confidence by depositors. It also finds that fundamental bank characteristics such as profitability and risk are typically not seriously affected by crises and rapidly converge back to benchmarks. This notwithstanding, intermediation to the private sector is curtailed in favor of the public sector. These results show a greater influence of supply factors on the reduction in bank lending.. Finally, we find evidence of increased holding of liquid assets and cash reserves. 
32. Some general policy conclusions for post-crisis recovery in bank fundamentals can be drawn from our results. The most fundamental recommendation is to implement policies that bring about a sustained increase of confidence in the banking system in order to promote longer-term deposits in domestic currency. As starting point, a stable macroeconomic environment alongside improved prudential institutional frameworks is a necessary condition. In addition, it is important to understand the structure of the banking system that may emerge after systemic crisis. This is critical if the less desirable effects of concentration and market segmentation are to be mitigated. For example, increased market share of public banks post-crisis may have a detrimental effect on the patterns of intermediation particularly to the private sector while a concentrated banking system may facilitate the maintenance of high spreads. 


\section{REFERENCES}

Barajas, A., and R. Steiner, 2002, "Credit Stagnation in Latin America," IMF Working Paper 02/53, (Washington: International Monetary Fund).

Barro, R.J., and X.X. Sala-i-Martin., 1992, “Convergence,” The Journal of Political Economy, 100(2), pp. 223-251.

Bernanke, B.S., 1983, "Non-Monetary Effects of Financial Crises in the Propagation of the Great Depression," The American Economic Review, 72, pp. 2547-76.

, M. Gertler, and S. Gilchrist, 1998, "The Financial Accelerator in a Quantitative Business Cycle Environment,” NBER Working Paper No. 6455.

Bleaney, M., S. Bougheas, and I. Skamnelos, 2008, “A Model of the Interactions between Banking Crises and Currency Crises," Journal of International Money and Finance, forthcoming.

Cadim de Carvalho, F. J., 1998, "The Real Stabilization Plan and the Banking Sector in Brazil," Banca Nazionale del Lavoro Quarterly Review, 206. Viewed $6^{\text {th }}$ June 2008 $<$ http://findarticles.com/p/articles/mi_qa5480/is_199809/ai_n21431483 $>$.

Caprio, G., and D. Klingebiel, 2003, "Episodes of Systemic and Borderline Financial Crises," World Bank Research Dataset, (Washington D.C: World Bank).

Dell'Ariccia, G., E. Detragiache, and R. Rajan, 2008, “The Real Effects of Banking Crises," Journal of Financial Intermediation, 17, pp. 89-112.

De Nicoló, G., P. Honohan, and A. Ize, 2003, "Dollarization of the Banking system: Good or Bad?” WB Policy Research Working Paper, 3116, (Washington: World Bank).

Demirgüç-Kunt, A, and E. Detragiache, 1997, "The Determinants of Banking Crises: Evidence from Industrial and Developing Countries," World Bank Policy Research Working Paper, No. 1828. , 1998, "The Determinants of Banking Crises: Evidence from Developing and Developed Countries,” IMF Staff Papers, 45 (1), pp. 81-109. , 2005, "Cross-Country Empirical Studies of Systemic Bank Distress: A Survey," National Institute Economic Review, 192 (1), pp. 68-83. , and P. Gupta, 2006a, "Inside the Crises: An Empirical Analysis of Banking Systems in Distress," Journal of International Money and Finance, 25, pp. 702-718. 
, and T. Tressel, 2006b, "Banking on the Principles: Compliance with Basel Core Principles and Bank Soundness," IMF Working Paper 06/242, (Washington: International Monetary Fund).

Gelos, Gaston R., 2006, "Banking Spreads in Latin America," IMF Working Paper 06/44, (Washington: International Monetary Fund).

Goldfajn, I., 2000, "The Swings in Capital Flows and the Brazilian Crisis," Working Paper, Pontifica Universidade Catolica, 422, (Rio de Janeiro, Brazil).

Gupta, P., 2005, "Aftermath of Banking Crises: Effects on Real and Monetary Variables," Journal of International Money and Finance, 24, pp. 675-691.

Hassan, K.M., and E.M. Hussain, 2006, "Depositor Discipline and Bank Risk-Taking Behavior: Evidence from the South-East Asian Financial Crises," NFI Working Paper No. 2006-WP-13.

The Heritage Foundation, 2008, 2008 Index of Economic Freedom, viewed on $10^{\text {th }}$ July 2008.

Honohan, P., 2005, "Stylized Facts From Recent Worldwide Experience", Prepared for the Norges Bank Conference "Banking Crises Resolution-Theory and Policy," Oslo, Viewed 6 June 2008.

Inter-American Development Bank, 2005, "Banking Crises Resolution," Chapter 5 in IPES Unlocking Credit: the Quest for Deep and Stable Lending, IPES, Washington D.C.

Kaminsky, G.L., and C.M. Reinhart, 1999, "The Twin Crises: The Causes of Banking and Balance-of-Payments Problems," The American Economic Review, 89 (3), pp. $473-500$.

Kaufmann, D., A. Kraay, and M. Mastruzzi, 2008, "Governance Matters VII: Aggregate and Individual Governance Indicators, 1996-2007," World Bank Policy Research Working Paper No.4654, (Washington D.C: World Bank).

Mankiw, G., D. Romer, and D. Weil, 1992, "A Contribution to the Empirics of Economic Growth," Quarterly Journal of Economics, 107 (2), pp. 407-437.

Mlachila, M., 2009, "Paraguay—Recurrent Financial Crises: Causes, Costs and Consequences," Chapter III, in Santos, A. (Ed.), Paraguay: Addresing the Stagnation and Instability Trap, (Washington: International Monetary Fund), forthcoming.

Sala-i-Martin X.X., 1996, "The Classical Approach to Convergence Analysis," The Economic Journal, 106 (437), pp. 1019-1036. 


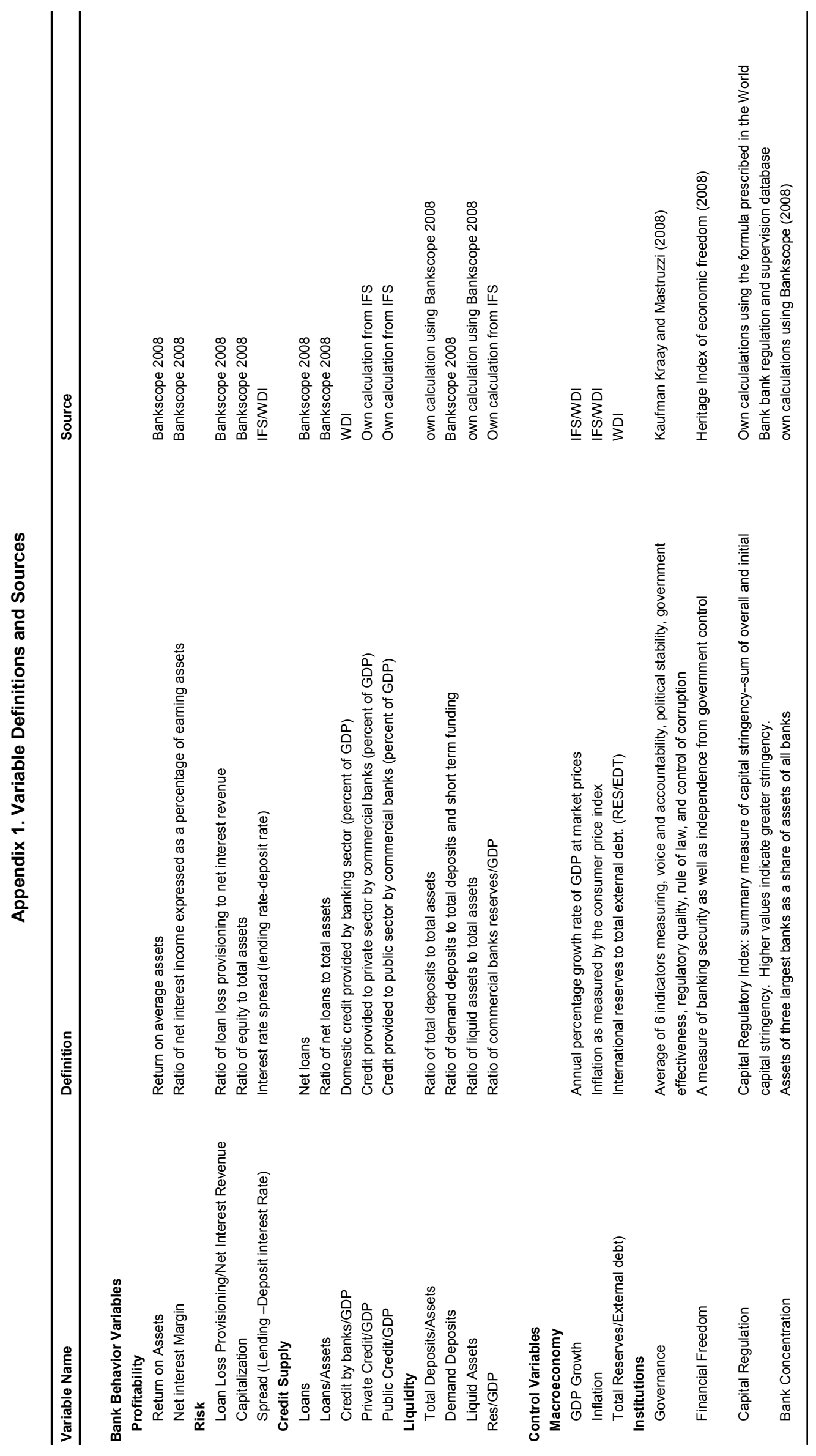

